\title{
A new Late Pleistocene fauna from arid coastal India: Implications for inundated coastal refugia and human dispersals
}

\author{
August G. Costa
}

\section{Rice University}

\section{Abstract}

A diverse Late Pleistocene fossil assemblage was recovered from a sea cliff locality near Gopnath in Gujarat, northwestern India. These remains are the first large sample of Pleistocene faunal materials from arid northwestern India. Several taxa known primarily from coarse alluvial deposits of central India are documented for the first time from an undisturbed open-air site adjoining the Great Indian Desert. The sample includes a new species of antelope from a lineage considered extinct outside of Africa since the Early Pleistocene. The paleoenvironmental context, faunal composition and type of fossil preservation reported here is unique. The Gopnath fauna accumulated in a pond within a carbonate dune field that formed part of a larger coastal oasis ecosystem. This paleoscape occupied the Cambay Gulf during hyper-arid glacial low stands. The Gopnath fossils are correlated to Late Acheulean lithics from a coastal cliff locality $(<8 \mathrm{~km})$ at Madhuban. These finds provide the first vertebrate evidence of glacial low stands and their influence on Late Pleistocene paleobiogeography within the dynamic dry coastal corridor linking India to Africa. They offer a rare glimpse of a lost landscape and an obscure fossil community that are critical to understanding the paleobiogeography of the hinterland along the Arabian seashore and informing models of early human dispersals.

Keywords: India, Late Pleistocene, Human dispersals, Mammalian Fauna, Late Acheulean, Paleoscapes

\section{Introduction}

The desert littoral of the north Arabian Sea plays a key role in many models of early human dispersal out of Africa and into southern Asia (Dennell and Petraglia, 2012; Field et al., 2007; Mellars, 2006a; Petraglia, 2007; Stringer, 2000). However, the tyranny of the fossil record in this area has proven nearly insurmountable (Boivin et al., 2013). No substantial fossil remains 
have been reported from the swath of arid lowlands linking Africa to India along the tropical Arabian coastline. Most of the Nubo-Sindian floral zone, from the Nile to the Indus Valley is a "black hole" of Pleistocene paleoanthropology and vertebrate paleobiology (Dennell and Roebroeks, 2005; Dennell, 2009). Although lithic evidence demonstrates that Pleistocene human groups occupied the interior of southern Arabia (Armitage et al., 2011; Delagnes et al., 2012; Petraglia et al., 2011; Rose, 2010; Rose et al., 2011) and the Sind-Thar Desert (Allchin et al., 1978; Biagi, 2008; Blinkhorn, 2012; Blinkhorn et al., 2013; Misra and Rajaguru, 1986; Misra, 1995a; Noguchi et al., 2012), few fossils are available to put these finds into an ecological context (Groucutt and Petraglia, 2012).

Despite enthusiasm for early human coastal migrations in southern Eurasia, there is little empirical evidence to support the assumption of a coastal route (Boivin et al., 2013). Most evidence for Late Pleistocene early human dispersals comes from inland areas suggesting that many early humans took the high-roads out of Africa (Boivin et al., 2013; Korisettar, 2007). Yet the limited preservation potential of dynamic marginal lowlands is expected, particularly along broad continental shelves where vast areas could have been exposed, submerged and or reworked by glacial-interglacial sea level flux. The scarcity of evidence is expected for a coastal dispersal, but remains problematic nonetheless. If early humans did follow a coastal superhighway out of Africa, we have little idea what that road may have been like.

This paper describes the first Late Pleistocene faunal assemblage recovered from the tropical Arabian coastal corridor. A large vertebrate collection from a glacial stage coastal oasis was recovered near Gopnath, on the Saurashtra peninsula in Gujarat State, northwestern India (Figure 1). The fossils come from the Gopnath Formation, a heavily weathered carbonate fossil dune system. No evidence of early humans was observed, however the Gopnath fauna are correlated to a previously reported Late Acheulean site at Madhuban (Marathe et al., 1995). The geologic context, taphonomy and species composition from the Gopnath site are reported here along with an assessment of the Madhuban lithic collection. Additional radiometric dating is needed, however the faunal composition, lithics and geological context indicate a broad Late Pleistocene age 125-12 thousand years ago (ka) for the Gopnath Formation.

\section{Background}




\subsection{South Asian Pleistocene Faunal Record}

Like elsewhere in the Nubo-Sindian zone, the Quaternary fossil record of South Asia is patchy. Although the Neogene strata of the Siwaliks (18 to 0.6 Ma) are one of the most complete successions of mammalian fauna in the world, the uppermost Early Pleistocene sediments (Boulder Conglomerate Formation) have yielded relatively few fossils. A significant shift in tectonics and basin geometries occurred near the beginning of the Quaternary in South Asia. These geodynamic developments left the area with high energy, course grained, and low resolution deposits which are much less favorable for preserving the recent fossil record.

The so-called "post-Siwalik" faunas of peninsular India and Sri Lanka are preserved mainly in coarse alluvial sediments and caves (Nanda, 2008). Several river valleys in peninsular India have yielded mostly later Pleistocene fossil remains, including the Narmada, Godavari, Son/Ganga, Manjra, Ghod, Krishna and Mahanandi (Chauhan, 2008). The Narmada Valley is exceptional in preserving the Early Pleistocene (Dhansi Formation. >780 ka) and later Middle to Late Pleistocene ( 250 ka to present, Surjakund Formation. and Baneta Formation. respectively) sequences (Patnaik et al., 2009). The Hathnora calvarium ( 200-80 ka), discovered in 1982 from the Middle Narmada Valley represents the only legitimate pre-anatomically modern Homo sapiens fossil in South Asia (Kennedy, 2000). Prior to these fossils there is a substantial gap in the Early to Middle Pleistocene fossil record of South Asia that covers the time spanning the end of the Siwaliks and the beginning of the post-Siwalik record ( 800-200 ka). This is unfortunate as many important extant South Asian taxa (e.g. Rhinoceros, Bos, and Equus) were in early stages of development at this time.

Many factors have limited fossil preservation in the South Asian Quaternary. A combination of low latitude and extreme seasonality caused by the onset of the Indian Summer Monsoon in addition to a lack of sedimentary basins due to the extensive bedrock coverage of the Deccan Trap flood basalts has resulted in a meager Quaternary fossil record in South Asia. In this setting Quaternary deposits cannot accumulate on a large scale except along fault bounded alluvial valleys.

Although caves and rockshelters have yielded Quaternary fossils, such finds are extraordinarily rare as most South Asian caverns have been disturbed by recent human activity, such as shrine or pilgrimage site construction (Allchin, 1971). At present most South Asian covered sites appear to be younger than 40,000 years BP (e.g., Clarkson et al., 2009; Perera et 
al., 2011; Roberts et al., 2015). However, the Acheulean component of Bhimbetka rockshelter is likely older than $40 \mathrm{ka}$ (Misra, 1995b) and new systematic dating at the Billasurgam Cave Complex demonstrates a continuous Late Quaternary (240 ka - Present) faunal record (Roberts et al., 2014). Closed sites are relatively rare in the western Indian states of Gujarat and Rajasthan. The rockshelters that have been investigated in Gujarat appear to be largely Holocene-aged Mesolithic sites with relatively little fauna (Ajithprasad, 2002a, 2002b; Sonawane, 2002).

Though scientists working in arid western India (i.e. Rajasthan and Gujarat States) have contributed immensely in describing the Quaternary succession of the region (Achyuthan et al., 2007; Chamyal et al., 2003; Juyal et al., 2006; Singhvi and Kar, 1992; Singhvi et al., 2010), few paleontological studies exist. Many finds of elephant, ostrich eggshell and other fossil remains have been noted, but usually in isolation (Badam, 1977; Blinkhorn et al., 2015; Paliwal, 2003). Most contributions on the biogeography and Quaternary paleoecology of large vertebrates in the region come from relatively recent faunal samples associated with Chalcolithic and Indus Valley Civilization sites (Meadow and Patel., 2003).

\subsection{Geological Context - Gujarat State}

Gujarat's Quaternary sediments consist of alluvium, dunes, beach rock and lacustrine deposits (Merh and Chamyal, 1993; Merh, 1995). At present no Quaternary deposits older than the last interglacial (i.e., $125 \mathrm{ka}$ ) are known from exposed surficial deposits in Gujarat (Chamyal et al., 2003; Mathur, 2005). The peninsular Gujarat region (Saurashtra) preserves a discontinuous Late Pleistocene record regulated by the flux of glacial versus interglacial sea-level and tectonic uplift of the Saurashtra block (Chamyal et al., 2003; Pant and Juyal, 1993). Late Pleistocene deposits in Saurashtra consist of alluvium marked by weak paleosols and Paleolithic assemblages, intermingled with carbonates occurring as marine, windblown, and valley-fill (i.e. alluvial) deposits (Baskaran, 1995; Bhatt and Bhonde, 2003; Bhatt, 2003; Marathe, 1981; Mathur, 2005; Merh and Chamyal, 1993).

These Late Pleistocene deposits provide ample evidence of drastic changes in sea level and recent neotectonism in the form of wave cut terraces (Bhatt and Bhonde, 2006; Pant and Juyal, 1993), knick points in river bed profiles (Marathe, 1981; Pappu and Marathe, 1977), and extensive subaerial/submarine coral platforms (Gupta, 1972; Kumar et al., 2005; V. P. Rao et al., 2003; Vora et al., 1996; Wagle et al., 1994). In the past, glacial low-stands exposed a 
considerable expanse of the broad, flat continental platform of western India, while interglacial sea level reduced available landmass considerably. The complexity of these recent dramatic changes in the landscape/seascape necessitates an integrated "paleoscape" approach (e.g. Fisher et al., 2010) to modeling the evolution of prehistoric Gujarat.

Granular carbonates of Saurashtra and Kutch known as "miliolite" or "Porbandar-stone" occur as eolian dunes, valley fill, and marine deposits (Bhatt, 2003; Mathur, 2005; Merh, 1995). Historically both eolian and tidal Quaternary carbonate deposits in Saurashtra were lumped together as "miliolites" even though these sediments accumulated in drastically different circumstances and at different times in the past. Numerous eolian accumulations, consisting primarily of fine granular carbonates (biopelsparites) are found on the southern slopes of hills located in the central part of the Saurashtra peninsula (Dasgupta and Bandyopadhyay, 2008). Wind-blown carbonate also occurs as valley-fill and appears as carbonate-enriched alluvium in many watersheds (e.g. Bhadar-Jetpur) from central Saurashtra. Both fossil (aeolianites) and active, unconsolidated, carbonate dunes are found along the southern coast of Saurashtra (Sperling, 1975). These wind-blown carbonates are the result of dramatic Late Pleistocene fluctuations in Gujarat's paleoclimate and paleoscape. Periodic glacial low stands exposed the continental platform of northwestern India, while interglacial winds associated with the Indian Summer Monsoon deflated these tropical carbonate factories during transitional phases (Biswas, 1971; Dasgupta and Bandyopadhyay, 2008). Most granular carbonates accumulated along the shifting shores and low valleys of Saurashtra. However, wind-blown foraminifera have been reported as far away as central Rajasthan ( 800 km north) (Goudie and Sperling, 1977).

\section{Setting}

Gopnath is a small fishing village of Talaja Taluka in southernmost Bhavnagar District, about $5.5 \mathrm{~km}$ south of the present mouth of the Shetrunji River (see Figure 1). It marks the most southeastern point of the Saurashtra peninsula as well as the boundary between the Gulf of Cambay and the Arabian Sea. Khadkikar and Basavaiah (2004) were the first to note vertebrate fossils at Gopnath. Subsequent investigations of the Gujarat Paleoanthropology Project (Costa et al., 2011), at Gopnath led to the discovery a large fossil vertebrate assemblage. A carbonate aeolianite forms a sea cliff ( $\sim 8 \mathrm{~m}$ high) south of Gopnath village. The upper part of this cliff includes a fossiliferous terra rossa-like horizon. Prior to discovery, six large blocks were 
undercut by wave action and broke away from the upper cliff face. The Gopnath fossil locality is the resulting cluster $(\sim 8 \times 8 \mathrm{~m})$ of rubble found on the beach within the high tide splash zone of the Cambay Gulf (Figure 2).

\subsection{Carbonate Aeolianites in Southeastern Saurashtra}

The Gopnath Formation is a vast expanse of carbonate aeolianite exposed as a wave cut cliff up to $40 \mathrm{~m}$ in height in the southeastern corner of Saurashtra (Khadkikar and Basavaiah, 2004; Patel and Bhatt, 1995). The dune system extends seaward to an unknown depth. Waves have eroded the subaerial part of the Gopnath Formation considerably landward (>500 $\mathrm{m}$ ) since the most recent Holocene transgression. However observations of sub-aqueous carbonate dunes elsewhere along Saurashtra shoreline suggests that some similar deposits have escaped the effects of transgressive ravinement.

The Gopnath Formation is heavily karstified and characterized by distinct red terra rossa (TR) or red paleosol horizons, which occur as laterally discontinuous bands or lenses. Extensive diagenesis has obscured many of the original sedimentary features and contacts in this formation. However, well-preserved outcrops show fine lamination $(2-3 \mathrm{~mm})$ and dipping $\left(20-28^{\circ}\right)$ largescale crossbeds. The Gopnath Formation reflects parabolic dunes with slightly convex up crossbedding and overlapping horns which became oriented transversely to southwesterly monsoon winds (Khadkikar and Basavaiah, 2004; Khadkikar, 2004).

Khadkikar and Basavaiah (2004) identified tentative evidence of rhizolith root casts and other features indicative of periods of landform stasis which they associated with the terra rossa horizons. Shells belonging to the small terrestrial gastropod Zootecus insularis are found throughout the Gopnath Formation. Faint vertebrate bone residues $(<5 \mathrm{~cm}$ max diameter) are also present in many outcrops. The fossils come from both carbonate and terra rossa horizons of the Gopnath Formation, but are generally sparse.

The age of the Gopnath Formation, like carbonates elsewhere in Saurashtra, is not well confined beyond the later Pleistocene (<200 -12ka). Although a great deal has been published on the probable ages of the Saurashtra carbonates (Baskaran, 1985; Baskaran et al., 1991, 1989a, 1989b, 1987, 1986; Bruckner, 1989; Gupta and Amin, 1974; Gupta, 1991), no reliable chronometric determinations have yet been achieved. Baskaran (1985) used Th/U to date over one hundred carbonate samples from Saurashtra as part of his doctoral research. However these 
results are problematic because: 1) the large error range in Th/U dating, (precision +/- 5\%) associated with the alpha spectrometry methodology, which is dependent on the measurement of radiometric decay rather than a quantification of the actual chemical elements present (Schwarcz, 1992), 2) unsound assumptions regarding the chemical purity of the carbonate samples analyzed, and 3) incomplete field characterizations.

Most age estimates are informed by Paleolithic stone tools found intermingled with the carbonates in Saurashtra (Marathe and Rajaguru, 1977; Marathe, 1981; Pappu and Marathe, 1977; Rajaguru et al., 2009). U-series dating of carbonate deposits associated with Paleolithic finds in Saurashtra suggests that the Acheulean may date to approximately 190-70 Ka, while the Middle Paleolithic likely predates $57 \mathrm{Ka}$ (Baskaran et al., 1986). Although these dates are problematic for the reasons mentioned above, they do support a broad Late Pleistocene age for most Paleolithic occurrences in the area. The upper age limit of the Gopnath Formation is the Holocene boundary as the carbonate sand source area, now submerged 50 fathoms offshore has not been exposed since the Last Glacial Maximum. These carbonate source sands have been dated to 9-11 ka (Khadkikar, 2004; V. Rao et al., 2003). The Gopnath Formation is Pleistocene in age.

\subsection{Madhuban Setting and Lithic Assemblage}

Madhuban village is located $8 \mathrm{~km}$ southwest of Gopnath. In 1993, fieldwork by Ashok Marathe recovered a Late Acheulean lithic assemblage $(n=92)$ from the Gopnath Formation near Madhuban (Marathe et al., 1995). These finds are the only evidence in South Asia of Acheulean tools stratified within the intertidal zone. Although the temporal range of the Late Acheulean ( 200-80? ka) is not firmly established in South Asia (Chauhan, 2009; Haslam et al., 2011), it is consistent with a later Pleistocene age for the carbonate aeolianite at Gopnath.

The Madhuban lithics were found within a narrow gravel lens $(1.2 \times 0.45 \mathrm{~m})$, possibly a small channel, developed within a terra rossa horizon located offshore on Bhensla Rock. This locale is a remnant headland now reduced to a small, wave-cut, sea stack/sea cave $\sim 100 \mathrm{~m}$ in length. This site is isolated from the mainland at high tide. Subsequent field visits have not uncovered further artifacts. It appears this vulnerable deposit was completely eroded away by wave action. 
Many large cutting tool types (handaxes 20, cleavers 23) were reported from the Madhuban assemblage (Figure 3). A small sample $(n=17)$ of the assemblage was available for detailed analysis (see Supplemental 1). The tools observed were large (mean $123 \mathrm{~mm} \max$ length), heavy (mean >550 g) and fairly worn. No chipping debris was observed and most artifacts were described as shaped tools (Marathe et al., 1995). Only cores and large unmodified flakes were present. Marathe et al. (1995) observed that specimens reflecting prepared-core techniques were present. Analysis of the Madhuban subset found evidence for centripetal flaking of boulder cores and one worn specimen (MB-69, see Figure 3b) that might be interpreted as a preferential Levallois core on a large flake. The cores include examples of finely made bifaces on aphanitic rhyolite, as well as more crude (thicker and more sinuous edged) specimens in andesite and mafic basalt.

\subsection{Gopnath Formation Stratigraphy and Depositional Models}

The Gopnath Formation presents a similar stratigraphic sequence at both Gopnath and Madhuban. Carbonate aeolianites extend offshore to an unknown depth. The lowermost observable Unit 1 comprises the expansive wave cut platform, which is exposed at low tide and exhibits a thin terra rossa horizon TR1 (Figure 4). Above this, Unit 2 forms part of the proximal wave cut platform. The latter unit outcrops near the high tide line and exhibits a prominent an erosional notch. The TR2 horizon overlays this and is commonly water saturated. The Acheulean finds at Madhuban came from this TR2 level. Another carbonate Unit 3 is superimposed on the latter and above this is TR3. This third terra rossa horizon is not well expressed at Madhuban, but is the same level that yielded the fossil assemblage at Gopnath. The sequence is capped by a distinct thick, crossbedded aeolianite (Unit 4) with Holocene soil at the surface. These observations are consistent with those of Khadkikar and Basavaiah, (2004), who proposed an event stratigraphy for the Gopnath Formation based upon the hypothesis that the terra rossa horizons represent breaks in carbonate deposition due to interglacial paleoclimatic conditions (namely decreased aridity) which favored paleosol development (Khadkikar, 2004; Patel and Bhatt, 1995). This cyclical sequence can be matched to a geomorphic model of carbonate deposition and soil formation that provide a coarse relative chronology for the Gopnath Formation. It is important to note however that Indian Summer Monsoon strength does not track

glacial excursions well (Liu, 2011), so this simple chronology needs further resolution, ideally 
based on local dated proxy records of monsoonal intensity rather than simplistic models based upon marine isotope stages.

\section{Methods}

When the fossil deposit at Gopnath was first discovered, the surf at high tide was actively mechanically and chemically destroying the recoverable deposit and its contents. By then an unknown portion of the fossiliferous deposit had already eroded away. High amplitude, semidiurnal tides came up twice daily and allowed little time ( $\sim 3$ hours /day) to work at the Gopnath locality safely. For these reasons fieldwork at Gopnath was a principally a salvage operation with an improvised sampling strategy.

Fossil remains were recovered as completely as possible according to the immediate circumstances. Preference was given to remains which were relatively complete and well preserved and those that were completely encased in matrix. A small portion of the Gopnath fossil assemblage was collected as loose surface finds on the beach. Fossils were extracted from arbitrarily numbered blocks. Fossil samples were removed by chisel as chunks in dimensions generally not exceeding 30x30 cm.

Nearly all of the fossils recovered from Gopnath required significant preparation and restoration, following recommended protocols (e.g., Kummel and Raup, 1965; Leiggi and May, 2005). The fossil remains were imbedded in a very hard carbonate matrix and required significant effort to liberate. Two Dremel® variable speed electrical engravers equipped with 1/8 inch tungsten-carbide cutter tips were used to remove matrix near bone. A Paleo-Tools® PaleoAro air scribe was used for heavy duty, high precision matrix removal. A chemical grade acetic acid bath was used to soften carbonate matrix. Several dental picks, chisels, awls and X-Acto ${ }^{\text {TM }}$ knives were also used for various matrix removal tasks. Low viscosity PALEO-BOND ${ }^{\mathrm{TM}}$ cyanoacrylate adhesive was used to join fragmented faunal remains. All remains were treated with a polyvinyl acetate consolidant dissolved in acetone.

All Gopnath specimens were prepared, studied and curated within the Department of Archaeology and Ancient History at the Maharaja Sayajirao University of Baroda. The comparative osteological collection of the latter was utilized extensively as an aid in faunal analysis. Faunal identification was also aided by several osteological reference texts (e.g., 
Gilbert, 1990; Hillson, 1999; Walker, 1985). Morphometric data and descriptions of perissodactyl fossils followed the guidelines published by Eisenmann et al (1988).

\section{Results}

\subsection{Gopnath Fauna}

The Gopnath vertebrate sample consists of 95 identifiable specimens belonging to a minimum of thirteen individuals who are attributed to eleven taxa from seven families (Table 1). The Gopnath assemblage is exceptionally diverse for a small sample composed of only a few individuals (Figure 5). The assemblage is dominated by bovids which comprise nearly half of all remains identified and $>30 \%$ of the estimated minimum number of individuals (MNI). Skeletal part representation is dominated by appendicular elements $(n=65)$, such as metapodials and other dense limb bones. Axial elements $(n=39)$ consist mostly of vertebrae and isolated teeth. Numerous Zootecus insularis shells were found scattered throughout the sediments at Gopnath. Many of these were closely associated with the vertebrate remains, resting on bone or within cavities. The Gopnath turtles include a terrestrial tortoise (Geochelone sp.), and a soft-shelled aquatic turtle (Nilssonia sp.).

The dental and appendicular elements of a single carnivore individual attributed to Canis sp. were recovered (Figure 6). The Gopnath Canis sp. mandibular remains are robust and the cheek teeth large, approximating those of the Early Pleistocene Canis cautleyi (Table 2). Muscles markings of the ulnae (GPN9, GPN16) were also strikingly robust. In all, the Gopnath

Canis remains appear to come from a large $(\sim 30 \mathrm{~kg})$ wolf unlike the modern southern wolf subspecies Canis lupus pallipes $(15-20 \mathrm{~kg}$ ), which is adapted to the warm arid environments of northwestern India.

Large fossil remains identified as Rhinoceros $c f$. R. unicornis from Gopnath included four axial and eleven appendicular specimens (Figure 7). The Gopnath fauna sample includes a minimum of two large and one or more small equids, attributed to Equus cf. E. sivalensis and Equus cf. E. hemionus respectively. The Gopnath equid sample is significant as it includes a partial skull (GPN24), in addition to the postcranial remains of a handful of individuals. (Figure 8) The presence of Asiatic ass (Equus cf. E. hemionus) is revealed by the occurrence of two diminutive adult humeri (GPN4, GPN12). 
The Bovidae are the most abundant group represented in the Gopnath cliff deposits. The tribes Boselaphini, Bovini and Reduncini are present in the Gopnath assemblage. The Gopnath bovid remains are entirely from large (size class 3 and 4) species and there is some ambiguity separating similar sized taxa (e.g. postcranial remains of boselaphines and reduncines, Bos and Bubalus). Nonetheless four bovid groups have been tentatively identified at Gopnath including: 1) Boselaphus sp., 2) Bubalus sp., 3) Bos sp., and the new reduncine 4) Sivacobus sankaliai (Vrba et al., 2015).

\subsection{Taphonomy}

No anthropogenic markings (i.e. cut marks) were observed on the Gopnath remains. Only six bones exhibited signs of postmortem disturbance or modification. One innominate (GPN102) showed signs of rodent gnawing. Other specimens were apparently broken or crushed prior to cementation in the dune sediments. Only three bones exhibit potential carnivore tooth pitting. The skeletal part and taxonomic composition of the Gopnath assemblage does not provide any indication of the sorting one would expect if animals or humans played a major role in the accumulation process. The damaged bones at Gopnath might be explained by passive animal trampling, however this alternative requires further study.

Fossils unaffected by recent erosive action of the intertidal splash zone at Gopnath are surprisingly fresh. All remains and their crevices (e.g. medullary cavities) were well impregnated by very fine clayey sand and granular carbonate. Most remains exhibited little exfoliation or cracking and were attributed to early weathering stages 1 or 2 (Behrensmeyer, 1978). The overall freshness of the remains and lack of animal modification suggest that the bones were buried rapidly following death.

No preferential orientation of fossils is observed at Gopnath. However, remains were found in both articulated and jumbled arrangements. Several large blocks recovered from Gopnath consisted of elements from unrelated taxa jumbled together. Yet, four articulated ungulate vertebrae (GPN17A-D) were also recovered. In all, the clustering of remains at Gopnath suggests moderate disturbance (likely by water) following skeletonization. The presence of numerous small elements (phalanges, isolated teeth, and gastropods $<1 \mathrm{~cm}$ ) suggests that winnowing was minimal. 


\section{Discussion}

\subsection{Gopnath Fauna}

The Gopnath fossil assemblage includes many exceptional finds. The discovery of a fossil skull from Gopnath (GPN119) attributable to the tribe Reduncini is particularly important as this group disappears from the Asian fossil record following the Early Pleistocene Pinjor Formation of the Siwalik Group (Nanda, 2008; Pilgrim, 1939). The discovery of this new species, Sivacobus sankaliai at Gopnath implies that the reduncine lineage persisted unrepresented in the fossil record of South Asia for close to a million years. This discovery is a vivid reminder that post-Siwalik record of peninsular India is far from complete. Likewise, the Gopnath Canis fossils are notable because there are few examples of Pleistocene-aged Canis remains from South Asia (Chauhan, 2008). The large size of the Gopnath canid also suggests that modern form of Indian wolf had not yet arrived by later Pleistocene times.

The rhino remains from Gopnath push back the first appearance datum of the greater onehorned Indian rhino (Rhinoceros unicornis) in northwestern India. Indian rhino remains have been previously reported in small quantities from Chalcolithic and Harappan sites in Gujarat (Chitawala, 1990; Clutton-Brock, 1965; Zeuner, 1952). Until 1600 A.D., Indian rhinos were common in northwestern India and Pakistan. However, agricultural development and overhunting since the colonial era have reduced Indian rhino populations to two small parks in northeastern India and Nepal. The presence of Indian rhino in arid northwestern India during historic and prehistoric times shows they were adaptable to a variety of South Asian environments. The historical record of rhino in Gujarat indicate that they favored the swampy, grassy plains (bhal) of northern Gujarat (Chitawala, 1990).

The discovery of Equus hemionus fossils at Gopnath is significant as Gujarat State is the only place where the southern Asiatic wild ass still persists. The Asiatic wild ass (E. hemionus) includes five geographic subspecies in central (dziggetai, kulan), southwestern (onager, hemippus-extinct) and southern (khur) Asia (Shah, 2004). The South Asian khur is presently restricted to the Little Rann of Kutch (Gujarat), having become extinct to the northwest (Makran Coast, Baluchistan, Sind and Thar Deserts) within the last hundred years (Hawkins, 1986).

Several Late Pleistocene fossils $(n=>8)$ from peninsular India have been attributed to the extant Asiatic Ass (see Table 1, Chauhan, 2008). A fossil metacarpal from Tejpur, in North 
Gujarat was ascribed to Equus cf. asinus (Badam, 1977), but likely represents E. hemionus khur (Costa, 2012). There is currently no record of Equus hemionus in South Asia prior to the Late Pleistocene (Biswas et al., 2005; Chauhan, 2008). Consequently, the occurrence of a hemionine ass (Equus cf. E. hemionus) in the Gopnath assemblage corroborates a broad Late Pleistocene age.

\subsection{Comparable Faunas}

The Gopnath fossils are the only assemblage of Pleistocene-aged remains in India situated south of New Delhi and west of Mumbai. Although its location is unique, the Gopnath fauna can be contrasted to assemblages reported from regions to the east and west. Chauhan (2008) provides a useful compilation of the mammalian taxa reported from the Late Quaternary of peninsular India. The most abundant taxa recorded from the Pleistocene of peninsular India are (in order of prevalence) the Bovidae, Proboscidea, Equidae, and Cervidae. This "big four" group (bovids, elephants, horses and deer) are found at most post-Siwalik fossil yielding sites in India. Consequently, the lack of elephant and deer in the current Gopnath fossil sample may be significant. One might speculate that arid conditions and limited mixed forest habitats would have made the latter groups scarce in Gujarat during glacial phases. Grasslands and grazers (i.e. some Bovids, Horses and Rhinos) would be able to populate and depopulate the shifting paleoscape much more rapidly than mixed vegetation, mixed feeders and browsers. Other taxa common to Pleistocene alluvial contexts in India such as suids, crocodilians, and hippopotamids are also lacking in the Gopnath sample. This lack of fauna typically associated with higher-order Pleistocene channel deposits from peninsular India supports a small inter-dune pond model for Gopnath.

Nearly all other comparable Pleistocene fossils from a broader area beyond the tropical Arabian coast are known exclusively from higher-altitude caves (e.g. Shanidar, Warwasi, Yafteh, Darra-I-Kur, Mt. Carmel) and thus primarily sample hominin/carnivore prey species and or cave dwelling fauna from a different physiographic zone (Mashkour et al., 2009). The extremely sparse fossil record available from the lower-latitude, open-air sites of Arabia include a few notable African taxa such as Alcelaphus, Oryx, Gazella, and hippopotamids (McClure, 1984; Thomas et al., 1998). Although both the chinkara gazelle (Gazella bennetti) and blackbuck (Antilope cervicapra) are abundant in modern Gujarat and Rajasthan, they are not yet resented in 
the Pleistocene fossil record. Many other modern or historical Indian vertebrates with African ties (Asiatic lion, cheetah, monkeys, mongoose, and flamingos) are also largely unknown from the prehistoric record.

The snail Zootecus is a common element of archeo-molluscan assemblages in the NuboSindian zone and is associated with Paleolithic finds in both Egypt/Sudan and western India (Butzer and Hansen, 1968; Mishra et al., 1999). Relatively little other specific overlap is evident between the fauna of these regions and Gopnath other than snails (Zootecus) and hemionine asses (Equus hemionus). The occurrence of hippo (Hexaprotodon) from analogous inter-dune lake environments in southern Arabia, and alluvial contexts in peninsular India suggests that additional efforts may uncover the latter at Gopnath.

\subsection{Gopnath Site Formation}

The discovery of a well-preserved fossil vertebrate assemblage at Gopnath adds further complexity to earlier models on the genesis of the carbonate aeolianite and terra rossa paleosols within the Gopnath Formation. Prior work suggested that the terra rossa paleosol horizons represent breaks in carbonate deposition due to interglacial paleoclimatic conditions which favored paleosol development (Khadkikar and Basavaiah, 2004; Khadkikar, 2004; Patel and Bhatt, 1995). It is doubtful that the Gopnath fossils could have preserved so well had they been subjected to prolonged periods of weathering needed to form terra rossa or paleosols in a wellcemented carbonate parent material. Gopnath Formation fossils are not unique to the terra rossa horizons, but are more concentrated and easily sampled in these outcroppings. An alternative hypothesis is needed to explain the: 1) the lack of better-preserved fauna in the aeolianite, 2) the concentration of fauna in some of the heavily weathered terra rossa horizons, and 3) the lateral discontinuity of the terra rossa horizons.

An oasis or series of oases in an otherwise arid land best explains the new data from Gopnath. The discontinuous terra rossa horizons in the Gopnath Formation may be interpreted as ephemeral inter-dune wetland deposits that have been transformed by preferential weathering associated with karstification. The absence of residual aeolianite in the matrix of the Gopnath fossil locale further supports the possibility of hitherto undetected lacustrine environments in the area. The occurrence of localized fresh-water resources also explains the diverse concentration of faunal remains at Gopnath. 
This interpretation is not exclusive of previous formation models for the Gopnath Formation. It is likely that epikarst weathering and small lacustrine accumulations were both forming at various times on the paleoscape. However the discontinuity of the terra rossa horizons and multiple processes that could have formed them suggests that that the coastal outcrops between Madhuban and Gopnath may reflect a single system of time equivalent dunes (carbonate aeolianites) and inter-dune wetlands (terra rossas) rather than a cyclical glacial-interglacial sequence (Costa, 2012). A further complicating factor is the likelihood that the ancient epikarstic features (paleosols and terra rossas) are masked or enhanced by modern weathering processes. Additional study and chronometric dating is needed to resolve these problems.

The Gopnath fossil site appears to be an ancient watering hole. The taphonomic evidence suggest that the Gopnath remains were deposited in a contained, relatively stagnant body of water- such as a pond- where decaying skeletal elements were scattered within a limited area and buried rapidly by fine-grained sediments. The composition of the Gopnath fauna supports this site formation model. The occurrence of turtles, especially the soft-shelled aquatic turtle (Nilssonia sp.) signals a nearby water source. Likewise the snail Zootecus insularis is an arid land, terrestrial species that prefers moist locations near lakes or rivers (Neubert, 2003). For instance, the presence of $Z$. insularis and other gastropods in arid northwestern India is thought to signal localized seasonal accumulation of standing water as puddles or inter-dune ponds (Mishra et al., 1999). The living relatives of the rhino (Rhinoceros unicornis) and water-buck (Sivacobus) are also commonly associated with well-watered habitats.

\subsection{Comparable Landscapes}

Carbonate aeolianites are not rare along the tropical Arabian seashore. Teller and colleagues (2000) described extensive Late Pleistocene, carbonate aeolianites from the United Arab Emirates which present the same mode of development as the Gopnath Formation. These locations lie within a tropical zone where carbonates are produced in abundance, and they have broad low-sloped continental margins which were severely deflated during glacial lowstands by strong unidirectional winds. The processes that created these carbonate aeolianite formations were operating on a broad scale across the Nubo-Sindhian area, yet fossils have never been described from these deposits in the Arabo-Persian Gulf area. 
The few Quaternary fossil finds known from the Arabian deserts come from inter-dune playa type microenvironments that are broadly similar to Gopnath (McClure, 1984; Petraglia and Alsharekh, 2003; Thomas et al., 1998). Moreover, the famous Late Pleistocene sites from the Willandra Lakes region of southeastern Australia (including the Mungo 3 inhumation, $40 \mathrm{ka}$ ), come from a series of lunette lakes associated with parabolic dunes (Allen and Holdaway, 2009; O'Connell and Allen, 2004; Webb et al., 2006). Unlike Gopnath however, the inter-dune pond sites of Arabia and Australia are known primarily from the hinterland rather than the coastal plain and thus contain little to no carbonate matrix. In sum, carbonate aeolianites containing Pleistocene vertebrate remains are very rare.

Coastal environments similar to Gopnath are expected for glacial low stand paleoscapes in the Arabian sea area (Parker and Rose, 2008; Rose, 2010). Increased groundwater flow (piezometric head) occurred on exposed continental shelves during glacial stages in response to lowered sea levels (Faure et al., 2002). In this fashion, glacial phase springs likely formed as groundwater pools in inter-dune depressions on the now submerged paleo-Shetrunji plain in a manner similar to that known from Sand Hills (Nebraska), the Lençóis Maranhenses (northeastern Brazil), and the lunette lakes of Australia (Loope et al., 1999; Luna et al., 2012; Sprigg, 1979). This coastal oasis phenomenon likely provided glacial stage refugia for floral and faunal communities not adapted to hyper arid conditions which prevailed in the hinterland due to the concurrent weakening of the Indian Summer Monsoon (Faure et al., 2002; Rose, 2010).

The paleoenvironment represented at Gopnath represents one portion of a larger dynamic and mosaic low stand paleoscape system (Figure 9). There are few modern or ancient analogs for the sort of environment implied here. Like the Pleistocene Palearctic mammoth steppe, the glacial low stand ecozones (e.g. Sundaland, Gulf of Cambay, Arabo-Persian Gulf, and Beringia) have no modern equivalents. However given basic parameters such as shifts in rainfall and shelf morphology, certain modern lowland biomes likely colonized the Cambay Gulf as glacial waters retreated. The modern salt-tolerant grassland communities or "bhal" of northern Gujarat are restricted to the northern Cambay area. However, the Late Pleistocene experienced average sea levels, $60 \mathrm{~m}$ lower than the present. This would have exposed a considerable paleoscape all along the Cambay shelf (Figure 10). Paleoenvironmental data from mainland Gujarat suggests a southward shift in arid lands (i.e. expansion of the Thar Desert) which roughly corresponds with phases of glacial hyper-aridity (Glennie et al., 2002; Juyal et al., 2003; Singhvi and Kar, 2004; 
Singhvi et al., 2010). These southward shifts in the desert and sea were likely accompanied by the ecozones in between. Many modern environments including the bhal habitat of northern Gujarat may have shifted south into the Cambay refugium during these periods. These grassy, well-watered habitats help explain the presence of rhino, reduncines and other fauna at a locale which would otherwise appear desolate.

\subsection{Human Evidence}

At present the Gopnath faunal site has not yielded evidence of prehistoric humans. No anthropogenic markings, breakage or sorting was observed amongst the Gopnath faunal sample. Even so, Gopnath presents unique bone preservation in a region where Late Pleistocene human occupation is well documented. As such, the Gopnath faunal site represents a critical location for future exploration to identify hominin fossils.

The age of Gopnath and its relationship to the Late Acheulean lithics at Madhuban require further resolution. The Gopnath Formation linking the Madhuban and Gopnath finds is too heavily weathered to make clear correlations. Nonetheless the Gopnath Formation deposits clearly indicate a low stand paleoscape facies unlike the present-day.

The Madhuban assemblage includes several examples of refined handaxes and cleavers with low edge sinuosity and well-centered edges. These specimens are consistent with the more sophisticated bifacial technology associated with the Late Acheulean. Some elements of the Madhuban assemblage (e.g. centripetal flaking, nearly discoid ovate bifacial cores) hint at prepared core strategies. The Madhuban lithic assemblage composition and condition, along with the apparent alluvial context suggests that hydrological sorting played a role in accumulating the site. It seems unlikely that tool manufacture took place on site. Current evidence suggests the Madhuban assemblage may represent a palimpsest or lag accumulation of artifact debris. The paleo-coastline was likely several kilometers seaward of its present position when the Madhuban lithics were accumulated within the Gopnath Formation. In sum, the Madhuban lithics do not directly imply Paleolithic exploitation of peri-coastal resources, but they do suggest human occupation of the inner coastal plain.

\subsection{Gopnath Formation Age}


The Gopnath Formation provides some of the first evidence along the Arabian seashore that is directly relevant to models emphasizing the importance of Ice Age refugia and coastal corridors. At present, the Gopnath fossils have not yielded collagen for Accelerator Mass Spectrometry (AMS) radiocarbon dating and attempts to apply optical dating to the aeolianite have not yet been fruitful. The Gopnath faunal assemblage appears to postdate Late Acheulean activity at Madhuban and is therefore likely to relate to the Late Pleistocene $\sim 125-12 \mathrm{ka}$.

The age of the Gopnath Formation finds are poorly constrained and require further resolution. Even so, the Quaternary of Gujarat has been well dated. The basal clay of the lower Mahi River is the only Quaternary deposit older than $125 \mathrm{ka}$ that is exposed at the surface (Juyal et al., 2000). On biochronological grounds the Gopnath fauna is consistent with a Late Pleistocene, post-Siwalik age. The geomorphic history of Saurashtra further suggests that the Gopnath Formation could only have accumulated after the Marine Isotope Stage (MIS) 5 transgression, when a combination of arid glacial climate and lowered sea levels facilitated the deflation of the exposed the carbonate rich continental shelf (MIS 4-2, 71-11 ka). Enhanced eolian activity would have followed MIS 4 and 2 as monsoon strength and shorelines returned to interglacial levels (see Figure 10).

\subsection{Implications for early human coastal corridors.}

Prolific fossil and archaeological finds from extraordinary circumstances have solidified Africa as a core region in mammalian evolution and human prehistory. The earliest examples of several major human biological and cultural developments are well documented in the PlioPleistocene of Africa. Advances in molecular anthropology since the 1980s have provided abundant support to models favoring a single later Pleistocene African origin and dispersal of modern Homo sapiens (Cann, 1988, 1987; Stringer and Andrews, 1988). In recent years these pro-migration paradigms have developed into dramatic narratives of early human exploration, interspecific conflict and or hybridization, and oceanic voyages in southern Eurasia (Oppenheimer, 2009; Petraglia and Allchin, 2007; Pringle, 2008; Stringer, 2000). Early dates for fossil and archaeological evidence of modern humans in Southeast Asia and Australia between 60 and $40 \mathrm{ka}$ and the phylogeography of modern human populations has persuaded many that a rapid coastal migration occurred on the North Indian Ocean rim prior to 50 ka (Bulbeck, 2007; Field et al., 2007; Macaulay et al., 2005; Mellars, 2006a, 2006b; O’Connell and Allen, 2004) and 
perhaps even $\sim 100 \mathrm{ka}$ (Boivin et al., 2013; Dennell and Petraglia, 2012). This development along with several others has increased interest in prehistoric seashores and inundated glacial landscapes as favorable habitats and corridors for early human and animal populations (Bailey, 2004; Bailey et al., 2008; Bailey and Flemming, 2008; Carrion et al., 2008; Erlandson and Fitzpatrick, 2006; Erlandson, 2001; Marean, 2011; McBrearty and Stringer, 2007; Westley and Dix, 2006).

The tropical Arabian coastline is particularly important for models of early human dispersal along a southern route out of Africa. Until now, the fossil record of the north Arabian seashore has been virtually non-existent. Nearly forty years ago, H.D. Sankalia predicted that the Saurashtra peninsula in western India would provide the "best proofs of early man's migration from Africa when the sea level was low" (1978:113). The evidence presented here has limitations, but still represents some of the best finds relevant to subject of coastal dispersals in the Arabian coastal zone. The fossil and lithic evidence from the Gopnath Formation allow for a new appreciation of coastal paleoenvironments during the critical period in which human dispersals may have occurred. Although these finds do not provide direct support to the hypothesis that early humans utilized the Arabian seashores extensively, they do provide some substantive data on a lost marginal paleoscape.

\section{Conclusions}

The Gopnath fossil assemblage accumulated in an inter-dune pond within a carbonate dune field that was part of an arid glacial paleoscape. This represents a new setting for Pleistocene fossil materials in a critical, yet poorly known region of the tropical Arabian coastline. Investigations of the faunal assemblage discovered at Gopnath represent the first substantial contribution on Pleistocene paleobiology in Gujarat State. The assemblage includes a new reduncine (Sivacobus sankaliai) that is unique in the Middle to Late Pleistocene record of Eurasia. This study grows the known paleobiogeographic ranges of several taxa (e.g. Rhino) into arid northwestern India. These finds also provide the first fossil evidence of Pleistocene glacial low stands and their effects on the paleoecology and paleoscape of southern Gujarat. The Gopnath fossils are complimentary to Acheulean artifacts recovered nearby at Madhuban (Marathe et al., 1995; Khadkikar and Basavaiah, 2004) which also indicate a more distant paleocoastline. These discoveries provide support to models which stress the potential of 
inundated Pleistocene paleoscapes as refugia and corridors for human and non-human species (Bailey, 2004; Bailey and Flemming, 2008; Bulbeck, 2007; Rose, 2010; Stringer, 2000). At present Gopnath has not yielded evidence of prehistoric humans. However the heterogeneous nature of the current faunal sample and its association with Late Acheulean lithics suggests that further investigations will be productive.

\section{Acknowledgements}

My thanks to Professor P. Ajithprasad and the Department of Archaeology and Ancient History at the MS University of Baroda for being gracious hosts and providing field and lab support for these studies. I thank K. Krishnan, K, Bhan, Ambika Patel, Bhanu Sharma, and Rajesh S.V. Special thanks to Abha Tripathi, Brad Chase, Melanie Everett, Faysal Bibi, and P. Joglekar for assistance in faunal identifications. I thank the staff and faculty at Deccan College Postgraduate and Research Institution (DCPRI) of Pune, India for their hospitality and permission to study artifact collections there. V. Shinde, M.D. Kajale, V. Sathe, Sheila Mishra, S. Rajaguru and A. Marathe facilitated my research at DCPRI. I thank the Archaeological Survey of India and the USIEF for providing research visa and fieldwork permissions. I thank Parth Chauhan, Jeanne Sept, Rachna Raj, Sheela Athreya, Jeff Fleisher and James Blinkhorn for their useful comments. Any errors or omissions in this work are entirely my own. This research was supported by the National Science Foundation (BCS-0932235), the L.S.B. Leakey Foundation, Sigma Xi, the Fulbright-Nehru (USIEF) fellowship program, and Indiana University.

\section{References}

Achyuthan, H., Quade, J., Roe, L., Placzek, K., 2007. Stable Isotope Composition of Pedogenic Carbonates from the Eastern Margin of the Thar Desert, Rajasthan, India. Quaternary International 162-163, 50-60.

Ajithprasad, P., 2002a. The pre-Harappan cultures of Gujarat, in: Settar, S., Korisettar, R. (Eds.),

Indian Archaeology in Retrospect Vol. II Protohistory: Archaeology of the Harappan Civilization. ICHR and Manohar, New Delhi, pp. 129-158.

Ajithprasad, P., 2002b. The Mesolithic Culture in the Orsang Valley, Gujarat, in: Mishra, V.D., Pal, J.N. (Eds.), Mesolithic India. University of Allahabad, Allahabad, pp. 154-189. 
Allchin, B., 1971. Blade and burin industries of West Pakistan and Western India, in: Hammond, N. (Ed.), South Asian Archaeology. Duckworth, London, pp. 39-50.

Allchin, B., Goudie, A., Hegde, K., 1978. The Prehistory and Palaeogeography of the Great Indian Desert. Academic Press, London.

Allen, H., Holdaway, S., 2009. The archaeology of Mungo and the Willandra Lakes: looking back, looking forward. Archaeology in Oceania 44, 96-106.

Armitage, S.J., Jasim, S.A., Marks, A.E., Parker, A.G., Usik, V.I., Uerpmann, H.-P.P., 2011. The Southern Route Out of Africa': Evidence for an Early Expansion. Science 331, 453-456.

Badam, G.L., 1977. First record of a Middle Palaeolithic fossil from Gujarat, India. Journal, Palaeontological Survey of India 20, 314-319.

Bailey, G., 2004. World Prehistory from the Margins: The Role of Coastlines in Human Evolution. Journal of Interdisciplinary Studies in History and Archaeology 1, 39-50.

Bailey, G., Carrion, J., Fa, D., Finlayson, C., Finlayson, G., Rodriguezvidal, J., 2008. The coastal shelf of the Mediterranean and beyond: Corridor and refugium for human populations in the Pleistocene. Quaternary Science Reviews 27, 2095-2099.

Bailey, G.N., Flemming, N.C., 2008. Archaeology of the continental shelf: Marine resources, submerged landscapes and underwater archaeology. Quaternary Science Reviews 27, 21532165.

Baskaran, M., 1995. The Origin of Quaternary Carbonate Deposits (Miliolites): a Theoretical Perspective. Memoirs, Geological Survey of India 32, 360-371.

Baskaran, M., 1985. Radiometric mineralogical and trace elemental studies of the Saurashtra Quaternary carbonate deposits: implications to their age and origin. Unpubl. Ph D thesis, Gujarat, Ahmedabad.

Baskaran, M., Deshpande, S. V, Rajaguru, S.N., Somayajulu, B.L.K., 1989a. Geochronology of Miliolite Rocks of Kutch, Western India. Journal, Geological Survey of India 33, 588-593.

Baskaran, M., Marathe, A.R., Rajaguru, S.N., Somayajulu, B.L.K., 1986. Geochronology of Palaeolithic Cultures in the Hiran Valley, Saurashtra, India. Journal of Archaeological Science 13, 505-514.

Baskaran, M., Rajagopalan, G., Somayajulu, B.L.K., 1991. 230Th/234U and 13C dating of Quaternary deposits of Saurashtra, India-Reply. Chemical Geology: Isotope Geoscience section $86,183-186$. 
Baskaran, M., Rajagopalan, G., Somayajulu, B.L.K., 1989b. 230Th/234U and 14C dating of the Quaternary carbonate deposits of Saurashtra, India. Chemical Geology: Isotope Geoscience section 79, 65-82.

Baskaran, M., Sahai, B., Sood, R.K., Somayajulu, B.L.K., 1987. Geochronolgical studies of strandlines of Saurashtra, India, detected by remote sensing techniques. International Journal of Remote Sensing 8, 169-176.

Behrensmeyer, A.K., 1978. Taphonomic and ecologic information from bone weathering. Paleobiology 4, 150-162.

Bhatt, N., 2003. The Late Quaternary Bioclastic Carbonate Deposits of Saurashtra and Kachchh, Gujarat Western India: A Review. Proceedings, Indian Academy of Science 69, 137-150.

Bhatt, N., Bhonde, U., 2006. Geomorphic expression of late Quaternary sea level changes along the southern Saurashtra coast, western India. Journal of Earth System Science 115, 395402.

Bhatt, N., Bhonde, U., 2003. Quaternary Fluvial Sequences of South Saurashtra, Western India. Current Science 84, 1065-1071.

Biagi, P., 2008. The Palaeolithic settlement of Sindh (Pakistan): a review. Archäologische Mitteilungen aus Iran und Turan 40, 1-26.

Biswas, S., Sonakia, A., Sitaramaiah, Y., 2005. A Skull of Equus Namadicus from the Middle Pleistocene Alluvial Deposits of Narmada Valley. Journal, Geological Survey of India 66, 438-444.

Biswas, S.K., 1971. The Miliolite Rocks of Kutch and Kathiawar (Western India). Sedimentary Geology 5, 147-164.

Blinkhorn, J., 2012. The Palaeolithic Occupation of the Thar Desert. Unpubl. Ph.D. thesis, Oxford Univ.

Blinkhorn, J., Achyuthan, H., Petraglia, M.D., 2015. Ostrich expansion into India during the Late Pleistocene: Implications for continental dispersal corridors. Palaeogeography Palaeoclimatology Palaeoecology 417, 80-90.

Blinkhorn, J., Achyuthan, H., Petraglia, M.D., Ditchfield, P., 2013. Middle Palaeolithic occupation in the Thar Desert during the Upper Pleistocene: the signature of a modern human exit out of Africa? Quaternary Science Reviews 77, 233-238. 
Boivin, N., Fuller, D.Q., Dennell, R., Allaby, R., Petraglia, M.D., 2013. Human dispersal across diverse environments of Asia during the Upper Pleistocene. Quaternary International 300, $32-47$.

Bruckner, H., 1989. Late Quaternary Shorelines in India, in: Scott, D.B. (Ed.), Late Quaternary Sea-Level Correlation and Applications. Kluwer Academic Publishers, pp. 169-194.

Bulbeck, D., 2007. Where River Meets Sea. Current Anthropology 48, 315-321.

Butzer, K.W., Hansen, C.L., 1968. Desert and river in Nubia: geomorphology and prehistoric environments at the Aswan Reservoir. University of Wisconsin Press.

Cann, R.L., 1988. DNA and Human Origins. Annual Review of Anthropology 17, 127-143.

Cann, R.L., 1987. In Search of Eve. Sciences 27, 30-37.

Carrion, J., Finlayson, C., Fernandez, S., Finlayson, G., Allue, E., Lopezsaez, J., Lopezgarcia, P., Gilromera, G., Bailey, G., Gonzalezsamperiz, P., 2008. A coastal reservoir of biodiversity for Upper Pleistocene human populations: palaeoecological investigations in Gorham's Cave (Gibraltar) in the context of the Iberian Peninsula. Quaternary Science Reviews 27, $2118-2135$.

Chamyal, L.S., Maurya, D.M., Raj, R., 2003. Fluvial systems of the drylands of western India: a synthesis of Late Quaternary environmental and tectonic changes. Quaternary International 104, 69-86.

Chauhan, P.R., 2009. The lower Paleolithic of the Indian subcontinent. Evolutionary Anthropology Issues, News, Reviews 18, 62-78.

Chauhan, P.R., 2008. Large mammal fossil occurrences and associated archaeological evidence in Pleistocene contexts of peninsular India and Sri Lanka. Quaternary International 192, 2042.

Chitawala, Y.M., 1990. The Disappearance of Rhino from Saurashtra: A Study in Palaeoecology. Bulletin, Deccan College Research Institute 49, 79-82.

Clarkson, C., Petraglia, M., Korisettar, R., Haslam, M., Boivin, N., Crowther, A., Ditchfield, P., Fuller, D., Miracle, P., Harris, C., 2009. The oldest and longest enduring microlithic sequence in India: 35,000 years of modern human occupation and change at the Jwalapuram Locality 9 rockshelter. Antiquity 83, 326-348.

Clutton-Brock, J., 1965. Excavations at Langhnaj: 1944-63. Part II: The Fauna, Poona. Deccan College Postgraduate and Research Institute, Poona. 
Costa, A.G., 2012. A Pleistocene Passage to India: The Paleoanthropology of Early Human Settlement in Coastal Western India. Unpubl. Ph. D. Thesis, Indiana Univ.

Costa, A.G., Ajithprasad, P., Sharma, B., 2011. Tracking Early Humans in coastal Western India: the Gujarat Palaeoanthropology Project. Antiquity 85.

Dasgupta, P., Bandyopadhyay, S., 2008. Carbonate aeolianites of western Saurashtra, India: experimental decipherment of the depositional mechanisms. Sedimentology 55, 1361-1374.

Delagnes, A., Tribolob, C., Bertrana, P., Breneta, M., Crassard, R., Jauberta, J., Khalidie, L., Mercierb, N., Nomadef, S., Peignég, S., Sitziaa, L., Tournepichea, J.-F., Al-Halibii, M., AlMosabii, A., Macchiarellij, R., 2012. Inland human settlement in southern Arabia 55,000 years ago. New evidence from the Wadi Surdud Middle Paleolithic site complex, western Yemen. Journal of Human Evolution. doi:http://dx.doi.org/10.1016/j.jhevol.2012.03.008

Dennell, R., 2009. The Palaeolithic Settlement of Asia. Cambridge University Press, Cambridge.

Dennell, R., Petraglia, M.D., 2012. The dispersal of Homo sapiens across southern Asia: how early, how often, how complex? Quaternary Science Reviews 47, 15-22.

Dennell, R., Roebroeks, W., 2005. An Asian perspective on early human dispersal from Africa. Nature 438, 1099-1104.

Dennell, R., Turner, A., Coard, R., Beech, M., Anwar, M., 2005. Two Upper Siwalik (Pinjor Stage) Fossil Accumulations from Localities 73 and 362 in the Pabbi Hills, Pakistan. Journal, Palaeontological Society of India 59, 101-111.

Eisenmann, V., Alberdi, M.T., De Giuli, C., Staesche, U., 1988. Volume I: Methodology, in: Woodburne, M., Sondaar, P. (Eds.), Studying Fossil Horses. E.J. Brill, Leiden, pp. 1-71.

Erlandson, J.M., 2001. The Archaeology of Aquatic Adaptations: Paradigms for a New Millennium. Journal of Archaeological Research 9, 287-350.

Erlandson, J.M., Fitzpatrick, S., 2006. Oceans, Islands, and Coasts: Current Perspectives on the Role of the Sea in Human Prehistory. Journal of Island and Coastal Archaeology 1, 5-32.

Faure, H., Walter, R.C., Grant, D.R., 2002. The coastal oasis: ice age springs on emerged continental shelves. Global and Planetary Change 33, 47-56.

Field, J.S., Petraglia, M.D., Lahr, M.M., 2007. The southern dispersal hypothesis and the South Asian archaeological record: Examination of dispersal routes through GIS analysis. Journal of Anthropology and Archaeology 26, 88-108. 
Fisher, E.C., Bar-Matthews, M., Jerardino, A., Marean, C.W., 2010. Middle and Late Pleistocene paleoscape modeling along the southern coast of South Africa. Quaternary Science Reviews 29, 1382-1398.

Gilbert, B.M., 1990. Mammalian Osteology. Missouri Archaeological Society, Columbia.

Glennie, K.W., Singhvi, A.K., Lancaster, N., Teller, J.T., 2002. Quaternary climatic changes over southern Arabia and the Thar desert, India, in: Clift, P.D., Gaedicke, C., Craig, J. (Eds.), Geological Society, London, Special Publications. Geological Society of London, London, pp. 301-316.

Goudie, A.S., Sperling, C.H.B., 1977. Long Distance Transport of Foraminiferal Tests by Wind in the Thar Desert, Northwest India. Journal of Sedimentary Petrology 47, 630-633.

Groucutt, H.S., Petraglia, M.D., 2012. The prehistory of the Arabian peninsula: Deserts, dispersals, and demography. Evolutionary Anthropology Issues, News, Reviews 21, 113125.

Gupta, S.K., 1991. $230 \mathrm{Th} / 234 \mathrm{U}$ and $14 \mathrm{C}$ Dating of Quaternary Carbonate Deposits of Saurashtra, India - Comments. Chemical Geology: Isotope Geoscience section 86, 179-186.

Gupta, S.K., 1972. Chronology of the Raised Beaches and Inland Coral Reefs of the Saurashtran Coast. Journal of Geology 80, 357-361.

Gupta, S.K., Amin, B.S., 1974. Io/U Ages of Corals from Saurashtra Coast. Marine Geology 16.

Haslam, M., Roberts, R.G., Shipton, C., Pal, J.N., Fenwick, J.L., Ditchfield, P., Boivin, N., Dubey, A.K., Gupta, M.C., Petraglia, M., 2011. Late Acheulean hominins at the Marine Isotope Stage 6/5e transition in north-central India. Quaternary Research 75, 670-682.

Hawkins, R.E., 1986. Encyclopedia of Indian Natural History. Published on behalf of the Bombay Natural History Society by Oxford University Press, Oxford.

Hillson, S., 1999. Mammal bones and teeth: an introductory guide to methods of identification. Institute of Archaeology UCL, London.

Juyal, N., Chamyal, L.S., Bhandari, S., Bhushan, R., Singhvi, a. K., 2006. Continental record of the southwest monsoon during the last 130ka: evidence from the southern margin of the Thar Desert, India. Quaternary Science Reviews 25, 2632-2650.

Juyal, N., Kar, A., Rajaguru, S.N., Singhvi, A.K., 2003. Luminescence chronology of aeolian deposition during the Late Quaternary on the southern margin of Thar Desert, India. Quaternary International 104, 87-98. 
Juyal, N., Raj, R., Maurya, D.M., Chamyal, L.S., Singhvi, A.K., 2000. Chronology of Late Pleistocene environmental changes in the lower Mahi basin, western India. Journal of Quaternary Science 15, 501-508.

Kennedy, K., 2000. God-apes and fossil men: paleoanthropology of South Asia. University of Michigan Press, Ann Arbor.

Khadkikar, A.S., 2004. Coastal Aeolianite Deposits: An Archive of Indian Monsoon Rainfall and Winds over the Late Quaternary. Journal, Geological Survey of India 64, 491-502.

Khadkikar, A.S., Basavaiah, N., 2004. Morphology, mineralogy and magnetic susceptibility of epikarst-Terra Rossa developed in late Quaternary aeolianite deposits of southeastern Saurashtra, India. Geomorphology 58, 339-355.

Korisettar, R., 2007. Toward Developing a Basin Model for Paleolithic Settlement of the Indian Subcontinent: Geodynamics, Monsoon Dynamics, Habitat Diversity and Dispersal Routes, in: Petraglia, M.D., Allchin, B. (Eds.), The Evolution and History of Human Populations in South Asia. Springer, pp. 69-96.

Kumar, A.A., Rao, V.P., Patil, S.K., Kessarkar, P.M., Thamban, M., 2005. Rock magnetic records of the sediments of the eastern Arabian Sea: Evidence for late Quaternary climatic change. Marine Geology 220, 59-82.

Kummel, B., Raup, D.M., 1965. Handbook of paleontological techniques. WH Freeman.

Leiggi, P., May, P., 2005. Vertebrate paleontological techniques. Cambridge Univ Press, Cambridge.

Liu, Z., 2011. Atmospheric science. Glacial cycles and Indian monsoon--a southern push. Science 333, 706-8.

Loope, D.B., Mason, J.A., Dingus, L., 1999. Lethal sandslides from eolian dunes. Journal of Geology 107, 707-713.

Luna, M., Parteli, E., Herrmann, H., 2012. Model for a dune field with exposed water table. Geomorphology.

Macaulay, V., Hill, C., Achilli, A., Rengo, C., Clarke, D., Meehan, W., Blackburn, J., Semino, O., Scozzari, R., Cruciani, F., Taha, A., Shaari, N.K., Raja, J.M., Ismail, P., Zainuddin, Z., Goodwin, W., Bulbeck, D., Bandelt, H.-J., Oppenheimer, S., Torroni, A., Richards, M., 2005. Single, Rapid Coastal Settlement of Asia Revealed by Analysis of Complete Mitochondrial Genomes. Science 308, 1034-1036. 
Marathe, A.R., 1981. Geoarchaeology of the Hiran Valley Saurashtra, India. Deccan College Postgraduate and Research Institute, Pune.

Marathe, A.R., Deodhar, P.G., Rajaguru, S.N., 1995. Costal Miliolite Formation and History of Early Man in Southern Saurashtra, in: Alsharahan, A.S., Glennie, K.W., Whittle, G.L. (Eds.), Quaternary Deserts and Climatic Change. Balkema, Rotterdam, pp. 601-607.

Marathe, A.R., Rajaguru, S.N., 1977. The Chronology of Early Man in Saurashtra. Recent Research in Geology 9, 133-144.

Marean, C.W., 2011. Coastal South Africa and the Coevolution of the Modern Human Lineage and the Coastal Adaptation, in: Bicho, N., Haws, J., Davis, L.G. (Eds.), Trekking the Shore. Springer, pp. 421-440.

Mashkour, M., Monchot, H., Trinkaus, E., Reyss, J.L., Biglari, F., Bailon, S., Heydari, S., Abdi, K., 2009. Carnivores and their prey in the Wezmeh cave (Kermanshah, Iran): a late Pleistocene refuge in the Zagros. International Journal of Osteoarchaeology 19, 678-694.

Mathur, U.B., 2005. Quaternary geology: Indian perspective: with notes on the Quaternary of Gujarat. Memoirs, Geological Survey of India 63, 344.

McBrearty, S., Stringer, C., 2007. Palaeoanthropology: The coast in colour. Nature 449, $793-$ 794.

McClure, H.A., 1984. Late Quaternary Palaeoenvironments of the Rub' Al Khali. Unpubl. Ph. D. Thesis, Univ. London.

Meadow, R.H., Patel., A.K., 2003. Prehistoric pastoralism in northwestern South Asia from the Neolithic to the Harappan Period, in: Weber, S., Belcher, W.R. (Eds.), Ethnobiology and the Indus Civilization. Lexington Books., Lanham, ML, pp. pp. 65-93.

Mellars, P., 2006a. Going East: New Genetic and Archaeological Perspectives on the Modern Human Colonization of Eurasia. Science 313, 796-800.

Mellars, P., 2006b. Why did modern human populations disperse from Africa ca. 60,000 years ago? A new model. Proceedings, National Academy of Sciences 103, 9381-9386.

Merh, S.S., 1995. Geology of Gujarat. Geological Society of India, Bangalore.

Merh, S.S., Chamyal, L.S., 1993. The Quaternary sediments in Gujarat. Current Science 64, $823-827$. 
Mishra, S., Jain, M., Tandon, S.K., Singhvi, A.K., Joglekar, P.P., Bhatt, S.C., Kshirsagar, A.A., Naik, S., Deshpande-Muhkerjee, A., 1999. Prehistoric Cultures and Late Quaternary Environments in the Luni Basin around Balotra. Man and Environment 24, 39-49.

Misra, V.N., 1995a. Geoarchaeology of the Thar Desert, Northwest India, in: Wadia, S., Korisettar, R., Kale, V.S. (Eds.), Quaternary Environments and Geoarchaeology of India Essays in Honour of S. N. Rajaguru, Memoirs Geological Society of India. Geological Society of India, Bangaldore, pp. 210-230 ST - Geoarchaeology of the Thar Desert, N.

Misra, V.N., 1995b. The Acheulian Sucession at Bhimbetka, Central India, in: Misra, V.N., Bellwood, P. (Eds.), Recent Advances in Indo-Pacific Prehistory. pp. 35-47.

Misra, V.N., Rajaguru, S.N., 1986. Environment et culture de l'homme prehistorique dans le desert du Thar, Rajasthan, Inde. L’Anthropologie 90, 407-437.

Nanda, A, 2008. Comments on the Pinjor Mammalian Fauna of the Siwalik Group in relation to the post-Siwalik faunas of Peninsular India and Indo-Gangetic Plain. Quaternary International 192, 6-13.

Neubert, E., 2003. The continental malacofauna of Arabia and adjacent areas, II. The genus Zootecus. Archiv für Molluskenkunde 132, 153-160.

Noguchi, A., Veesar, G.M., Mallah, Q.H., Shaikh, N., Kondo, H., 2012. Recent Research on Palaeolithic sites in the Thar Desert, Sindh, Pakistan and its implications for modern human dispersal into South Asia, in: European Association for South Asian Archaeology and Art Conference 2012.

O’Connell, J.F., Allen, J., 2004. Dating the colonization of Sahul (Pleistocene Australia-New Guinea): a review of recent research. Journal of Archaeological Science 31, 835-853.

Oppenheimer, S., 2009. The Great Arc of Dispersal of Modern Humans: Africa to Australia. Quaternary International 202, 2-13.

Paliwal, B.S., 2003. Fossilzed Elephant Bones in the Quaternary Gypsum Deposits at Bhandawesi, Naguar District, Rajasthan. Current Science 84, 1188-1191.

Pant, R.K., Juyal, N., 1993. Late Quaternary coastal instability and sea level changes: New evidences from Saurashtra coast, Western India. Zeitschrift fuer Geomorphologie 37, 2940.

Pappu, R.S., Marathe, A.R., 1977. Geomorphology and Early Man in Saurashtra. Recent Research in Geology 9, 159-169. 
Parker, A.G., Rose, J.I., 2008. Climate change and human origins in southern Arabia. Proceedings of the Seminar for Arabian Studies 38, 25-42.

Patel, M.P., Bhatt, N., 1995. Evidence of Palaeoclimatic Fluctuations in Miliolite Rocks of Saurashtra, Western India. Journal, Geological Survey of India.

Patnaik, R., Chauhan, P.R., Rao, M.R., Blackwell, B. a B., Skinner, a R., Sahni, A., Chauhan, M.S., Khan, H.S., 2009. New geochronological, paleoclimatological, and archaeological data from the Narmada Valley hominin locality, central India. Journal of Human Evolution. $56,114-33$.

Perera, N., Kourampas, N., Simpson, I.A., Deraniyagala, S.U., Bulbeck, D., Kamminga, J., Perera, J., Fuller, D.Q., Szabó, K., Oliveira, N. V, 2011. People of the ancient rainforest: Late Pleistocene foragers at the Batadomba-lena rockshelter, Sri Lanka. Journal of Human Evolution 61, 254-269.

Petraglia, M.D., 2007. Mind the Gap: Factoring the Arabian Peninsula and the Indian Subcontinent into Out of Africa Models, in: Mellars, P., Bar-Yosef, O., Boyle, K., Stringer, C. (Eds.), The Human Revolution Revisited. McDonald Institute Archaeological Publications, Cambridge, pp. 383-394.

Petraglia, M.D., Allchin, B., 2007. The Evolution and History of Human Populations in South Asia: Inter-disciplinary Studies in Archaeology, Biological Anthropology, Linguistics and Genetics. Springer Science \& Business Media.

Petraglia, M.D., Alsharekh, A., 2003. The Middle Palaeolithic of Arabia: Implications for modern human origins, behaviour and dispersals. Antiquity 77, 671-684.

Petraglia, M.D., Alsharekh, A.M., Crassard, R., Drake, N. a., Groucutt, H., Parker, A.G., Roberts, R.G., 2011. Middle Paleolithic occupation on a Marine Isotope Stage 5 lakeshore in the Nefud Desert, Saudi Arabia. Quaternary Science Reviews 30, 1555-1559.

Pilgrim, G.E., 1939. The Fosil Bovidae of India. Palaeontol. Indica. Memoirs, Geological Survey of India 26, 1-356.

Pringle, H., 2008. Did Humans Colonize the World by Boat? Discovery Magazine 8-11.

Rajaguru, S.N., Pappu, S., Deo, S., Mishra, S., 2009. Earth Sciences and the Lower Palaeolithic:

Recent Research and Future Prospects, in: Paddayya, K., Joglekar, P.P., Basa, K., Sawant, R. (Eds.), Recent Research Trends in South Asian Archaeology. Deccan College Postgraduate and Research Institute, Pune, pp. 79-93. 
Rao, V., Montaggioni, L., Vora, K.H., Almeida, F., Rao, K.M., Rajagopalan, G., 2003. Significance of relic carbonate deposits along the central and southwestern margin of India for late Quaternary environmental and sea level changes. Sedimentary Geology 159, 95 111.

Rao, V.P., Rajagopalan, G., Vora, K.H., Almeida, F., 2003. Late Quaternary sea level and environmental changes from relic carbonate deposits of the western margin of India. Proceedings, Indian Academy of Scences, Earth and Planetary Sciences 112, 1-25.

Roberts, P., Delson, E., Miracle, P., Ditchfield, P., Roberts, R.G., Jacobs, Z., Blinkhorn, J., Ciochon, R.L., Fleagle, J.G., Frost, S.R., Gilbert, C.C., Gunnell, G.F., Harrison, T., Korisettar, R., Petraglia, M.D., 2014. Continuity of mammalian fauna over the last 200,000 $\mathrm{y}$ in the Indian subcontinent. Proceedings, National Academy of Sciences 111, 5848-5853.

Roberts, P., Perera, N., Wedage, O., Deraniyagala, S., Perera, J., Eregama, S., Gledhill, A., Petraglia, M.D., Lee-Thorp, J.A., 2015. Direct evidence for human reliance on rainforest resources in late Pleistocene Sri Lanka. Science 347, 1246-9.

Rose, J.I., 2010. New Light on Human Prehistory in the Arabo-Persian Gulf Oasis. Current Anthropology 51, 849-883.

Rose, J.I., Usik, V.I., Marks, A.E., Hilbert, Y.H., Galletti, C.S., Parton, A., Geiling, J.M., Černý, V., Morley, M.W., Roberts, R.G., 2011. The Nubian Complex of Dhofar, Oman: An African Middle Stone Age Industry in Southern Arabia. PLoS One 6, e28239.

Schwarcz, H.P., 1992. Uranium series dating in paleoanthropology. Evolutionary Anthropology $1,56-62$.

Shah, N., 2004. Ungulates of India: Indian Wild Ass or Khur. Envis Bulletin, Wildlife Institute of India 7, 1-7.

Singhvi, A.K., Kar, A., 2004. The Aeolian Sedimentation Record of the Thar Desert. Proceedings, Indian Academy of Science, Earth and Planetary Sciences 113, 371-401.

Singhvi, A.K., Kar, A., 1992. Thar Desert in Rajasthan: Land, Man and Environment. Geological Society of India, Bangalore.

Singhvi, A.K., Williams, M.A.J., Rajaguru, S.N., Misra, V.N., Chawla, S., Stokes, S., Chauhan, N., Francis, T., Ganjoo, R.K., Humphreys, G.S., 2010. A 200 ka record of climatic change and dune activity in the Thar Desert. Quaternary Science Reviews 29, 3095-3105. 
Sonawane, V.H., 2002. Mesolithic Culture in Gujarat, in: Pal, J.N. (Ed.), Mesolithic India. University of Allahabad, Allahabad, pp. 104-153.

Sperling, C.H.B., 1975. The Miliolite of Western India - A Discussion of the Aeolian and Marine Hypothesis. Sedimentary Geology 13, 71-75.

Sprigg, R.C., 1979. Stranded and Submerged Sea-Beach Systems of Southeast South Australia and the Aeolian Desert Cycle. Sedimentary Geology 22, 53-96.

Stringer, C., 2000. Coasting out of Africa. Nature 405, 24-26.

Stringer, C., Andrews, P., 1988. Genetic and fossil evidence for the origin of modern humans. Science 239, 1263-1268.

Teller, J.T., Glennie, K.W., Lancaster, N., Singhvi, A.K., 2000. Calcareous dunes of the United Arab Emirates and Noah's Flood: the postglacial reflooding of the Persian (Arabian) Gulf. Quaternary International 71, 297-308.

Thomas, H., Geraads, D., Janjou, D., Vaslet, D., Memseh, A., Billiou, D., 1998. Découverte des premières faunes pléistocene de la peninsula Arabique dans le désert du Nafoud (Arabie Saoudite). Compte Rendu l'Academie des Sci. Paris 326, 145-152.

Vora, K.H., Wagle, B.G., Veerayya, M., Almeida, F., Karisiddaiah, S.M., 1996. 1300 km long late Pleistocene-Holocene shelf edge barrier reef system along the western continental shelf of India: occurrence and significance. Marine Geology 134, 145-162.

Vrba, E.S., Bibi, F., Costa, A.G., 2015. First Asian record of a late Pleistocene reduncine (Artiodactyla, Bovidae, Reduncini), Sivacobus sankaliai, sp. nov., from Gopnath (Miliolite Formation) Gujarat, India, and a revision of the Asian genus Sivacobus Pilgrim, 1939. Journal of Vertebrate Palaeontology.

Wagle, B.G., Vora, K.H., Karisiddaiah, S.M., Veerayya, M., Almeida, F., 1994. Holocene submarine terraces on the western continental shelf of India; Implications for sea-level changes. Marine Geology 117, 207-225.

Walker, R., 1985. A Guide to Post-cranial Bones of East African Animals: Mrs Walker's Bone Book. Hylochoerus Press, Norwich.

Walter, R.C., Buffler, R.T., Bruggemann, J.H., Guillaume, M.M., Berhe, S.M., Negassi, B., Libsekal, Y., Cheng, H., Edwards, R.L., von Cosel, R., 2000. Early human occupation of the Red Sea coast of Eritrea during the last interglacial. Nature 405, 65-69. 
Webb, S., Cupper, M.L., Robins, R., 2006. Pleistocene human footprints from the Willandra Lakes, southeastern Australia. Journal of Human Evolution 50, 405-413.

Westley, K., Dix, J., 2006. Coastal environments and their role in prehistoric migrations. J. Maritime Archaeology 1, 9-28.

Zeuner, F.E., 1952. The Microlithic Industry of Langhnaj, Gujarat. Man 52, 129-131.

\section{List of Tables}

Table 1. Fossil fauna from Gopnath.

Table 2. Gopnath Canis sp. comparative metrics for mandibular dentition. *Indicates approximation. Data compiled from Dennell et al. (2005) and Clutton-Brock (1965).

\section{List of Figures}

Figure 1. Gopnath Formation location in Gujarat western India.

Figure 2. Gopnath sea cliff looking west. Sampled fossil area highlighted and blocks labeled. Arrows orient blocks toward stratigraphic up. Scale bars equal $1 \mathrm{~m}$ each.

Figure 3 - Selected Late Acheulean lithics from Madhuban. A) small bifaces, B) apparent prepared core on large flake, C) cleaver, D) large flake, E) large bifacial core. Scale bars equal 5 $\mathrm{cm}$.

Figure 4. Composite succession of coastal carbonate aeolianites and terra rossa deposits in southeastern Bhavnagar (Gopnath Formation). Relative chronology is based on alternating environmental conditions and the assumption that the Indian Summer Monsoon tracks global glacial-interglacial phases.

Figure 5. Vertebrate taxa represented in the Gopnath fauna sample with abundances (NISP/MNI) indicated. 
Figure 6. Selected Gopnath Canis sp. specimens. A) right hemi-mandible (GPN10) medial view; B) left hemi-mandible (GPN1) lateral view; C) left scapula (GPN8) glenoidal (left) and dorsallateral (right) aspects; D) clockwise from top, left ulna (GPN9) lateral view, 3rd or 4th metatarsal (GPN104) side view, proximal (GPN34) and intermediate phalange anterior view (GPN108). Scale bars equal $5 \mathrm{~cm}$.

Figure 7. Selected Gopnath appendicular remains of Rhinoceros $c f$. unicornis A) left humerus in anterior and posterior views, B) nearly complete radius, C) left patella, D) two left calcanei, E) left astragalus, and F) left scaphoid. Scale bars equal $5 \mathrm{~cm}$.

Figure 8. Partial cranium of Equus cf. sivalensis (GPN24) right lateral and left lateral views. Scale bar equals $5 \mathrm{~cm}$.

Figure 9. Map of Gopnath-Madhuban study area juxtaposed with inferred paleoscape features.

Figure 10. Contrasting paleoscape maps of western Indian during A) the last interglacial (MIS5e) highstand when Saurashtra was cut off from the mainland, and B) an arid glacial phase lowstand where carbonate aeolianites like the Gopnath Formation were being deposited. 


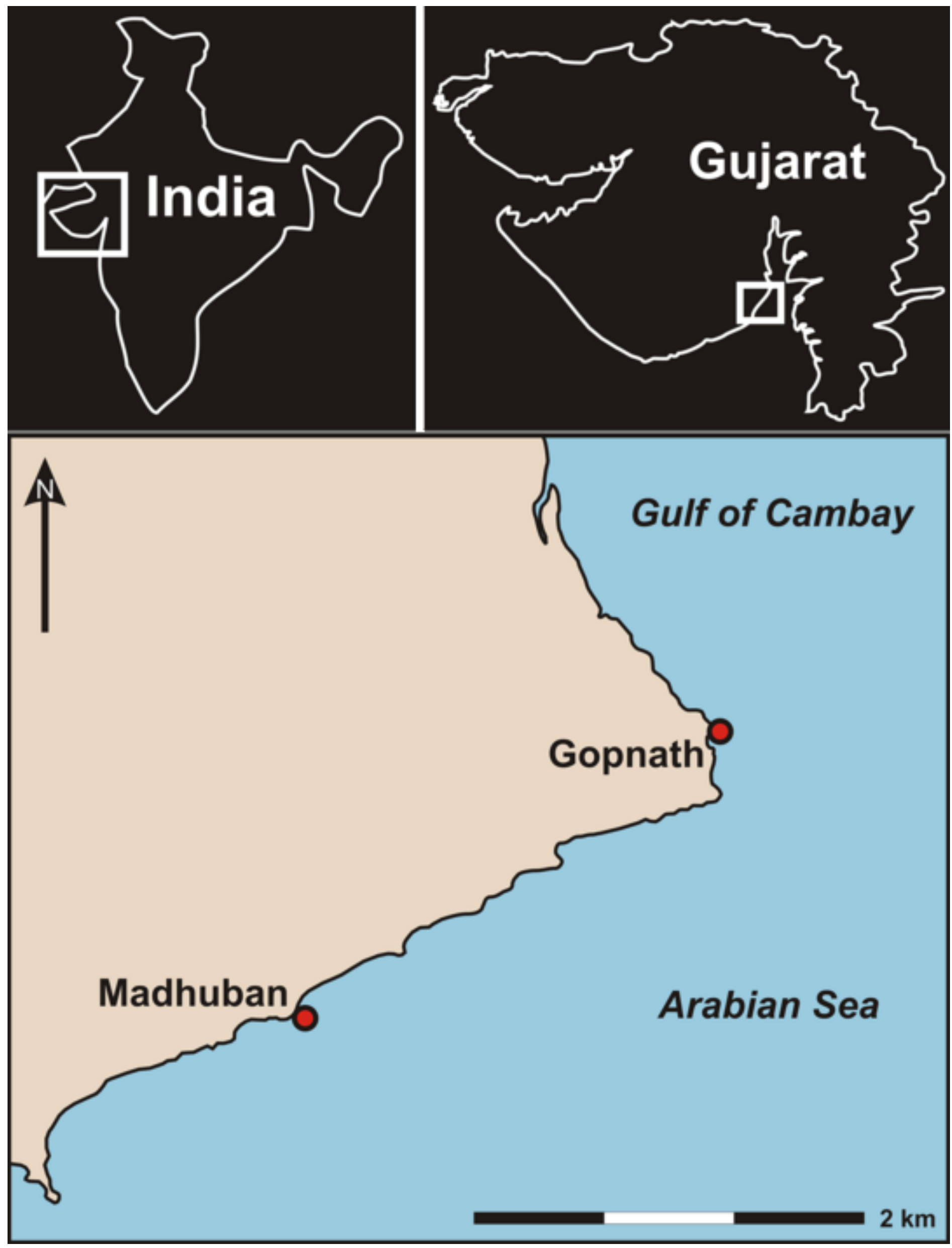




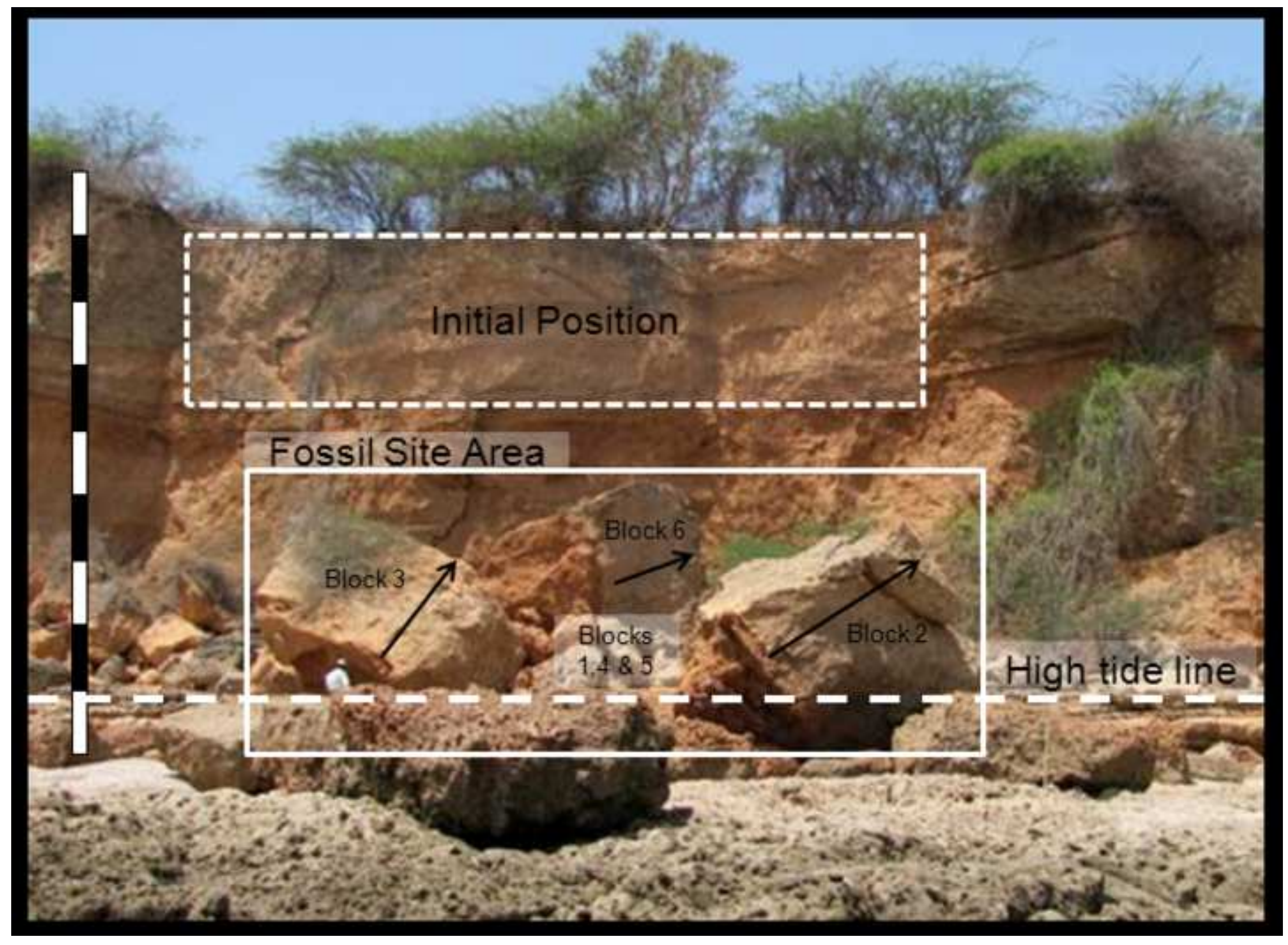



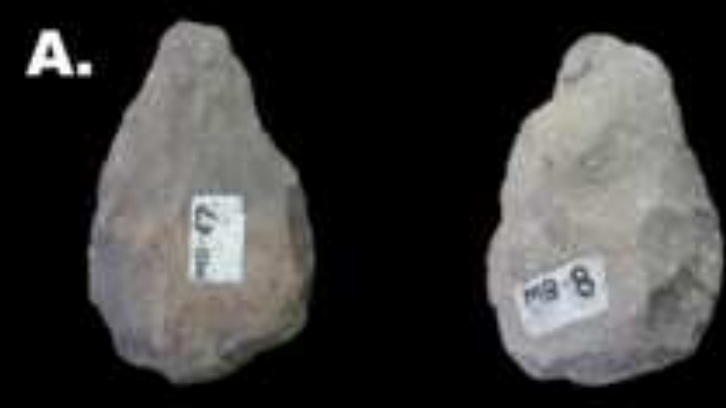

B.

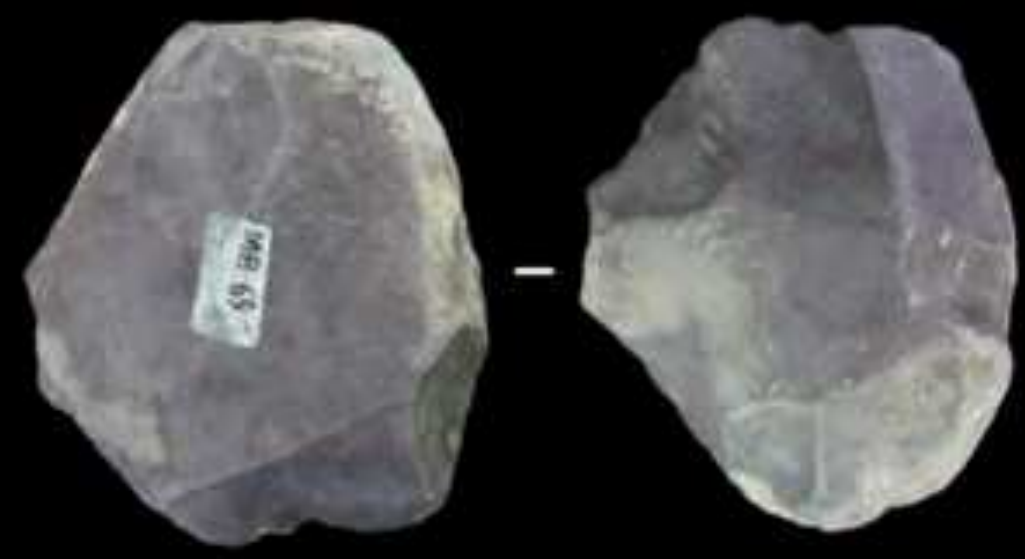

D.

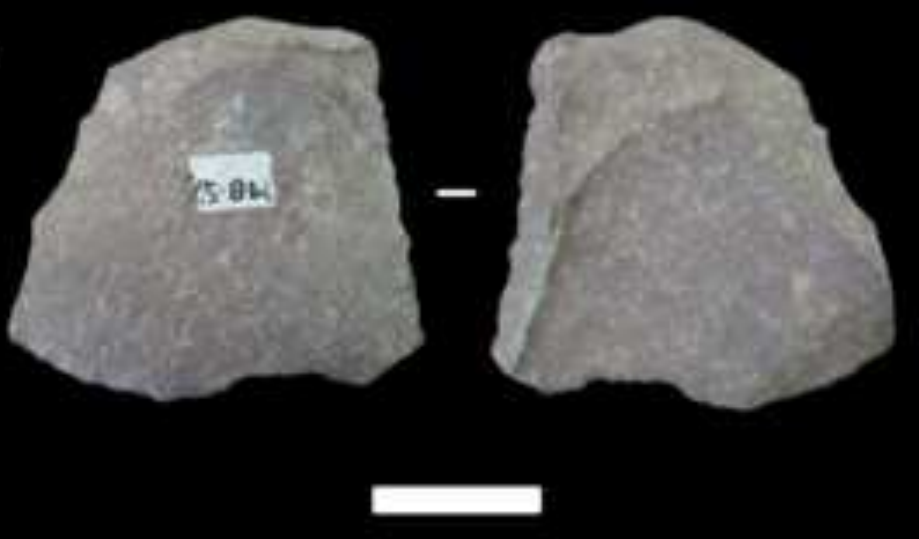

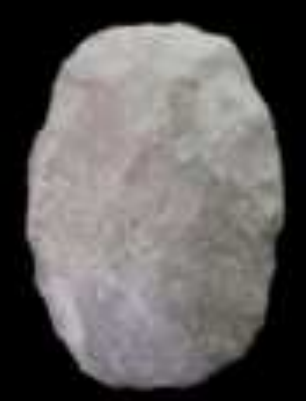

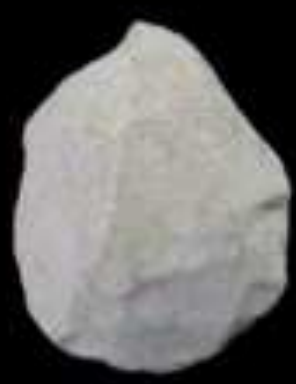

c.
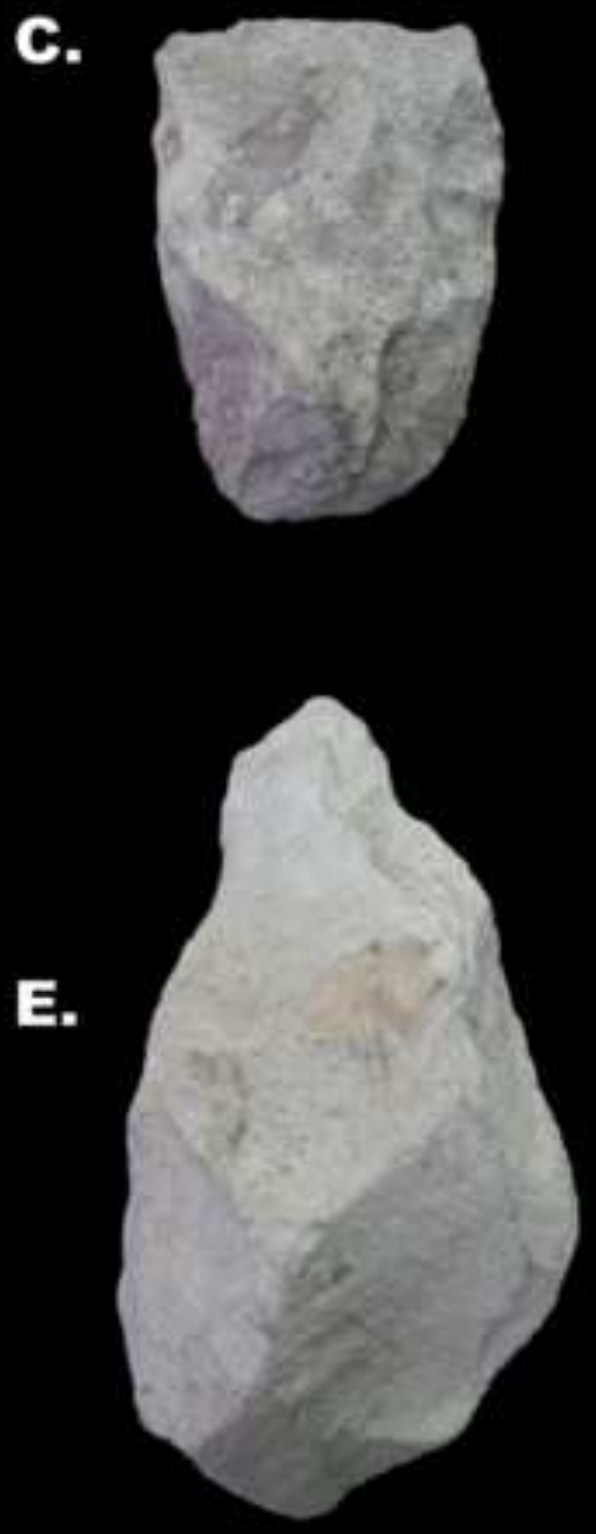


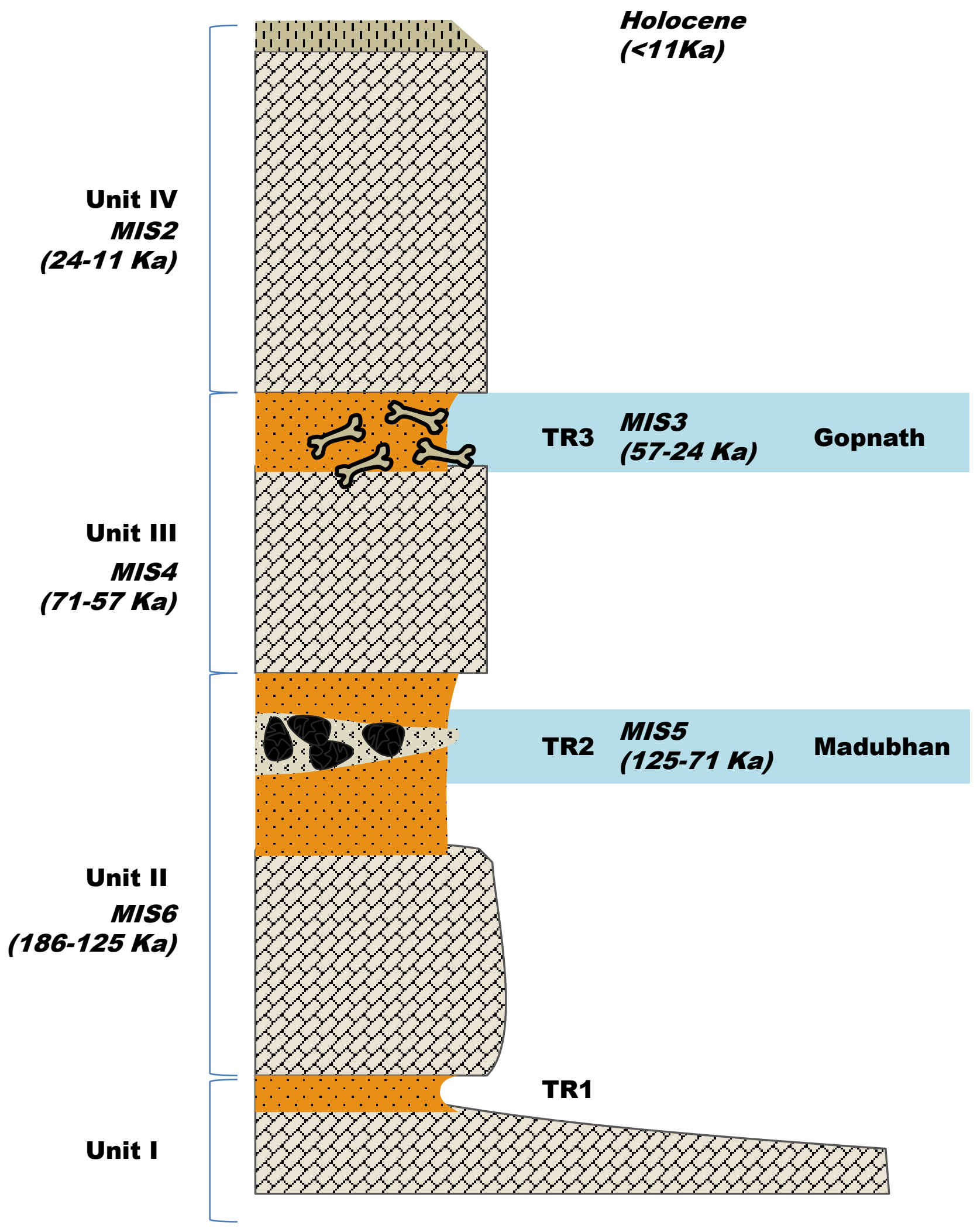




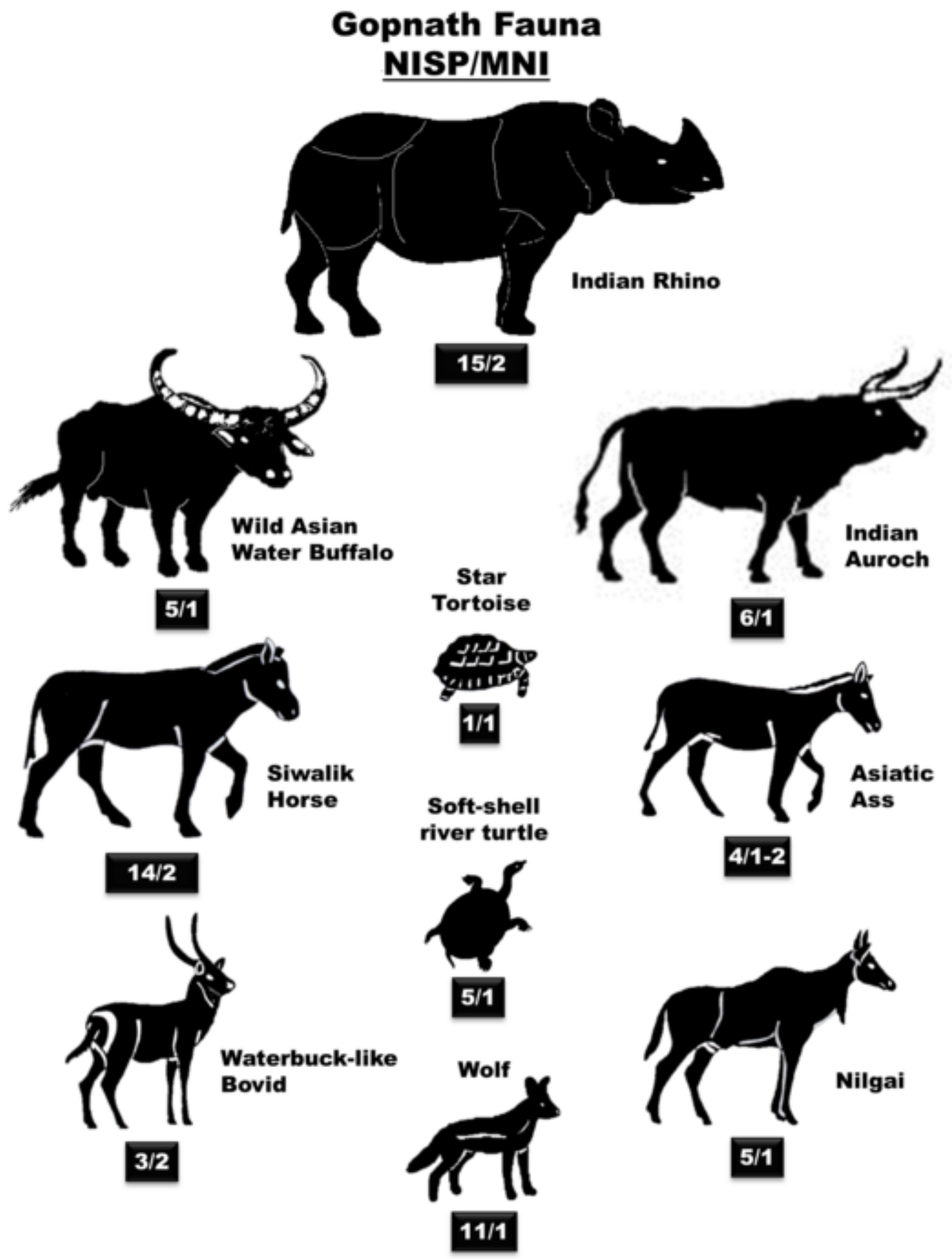




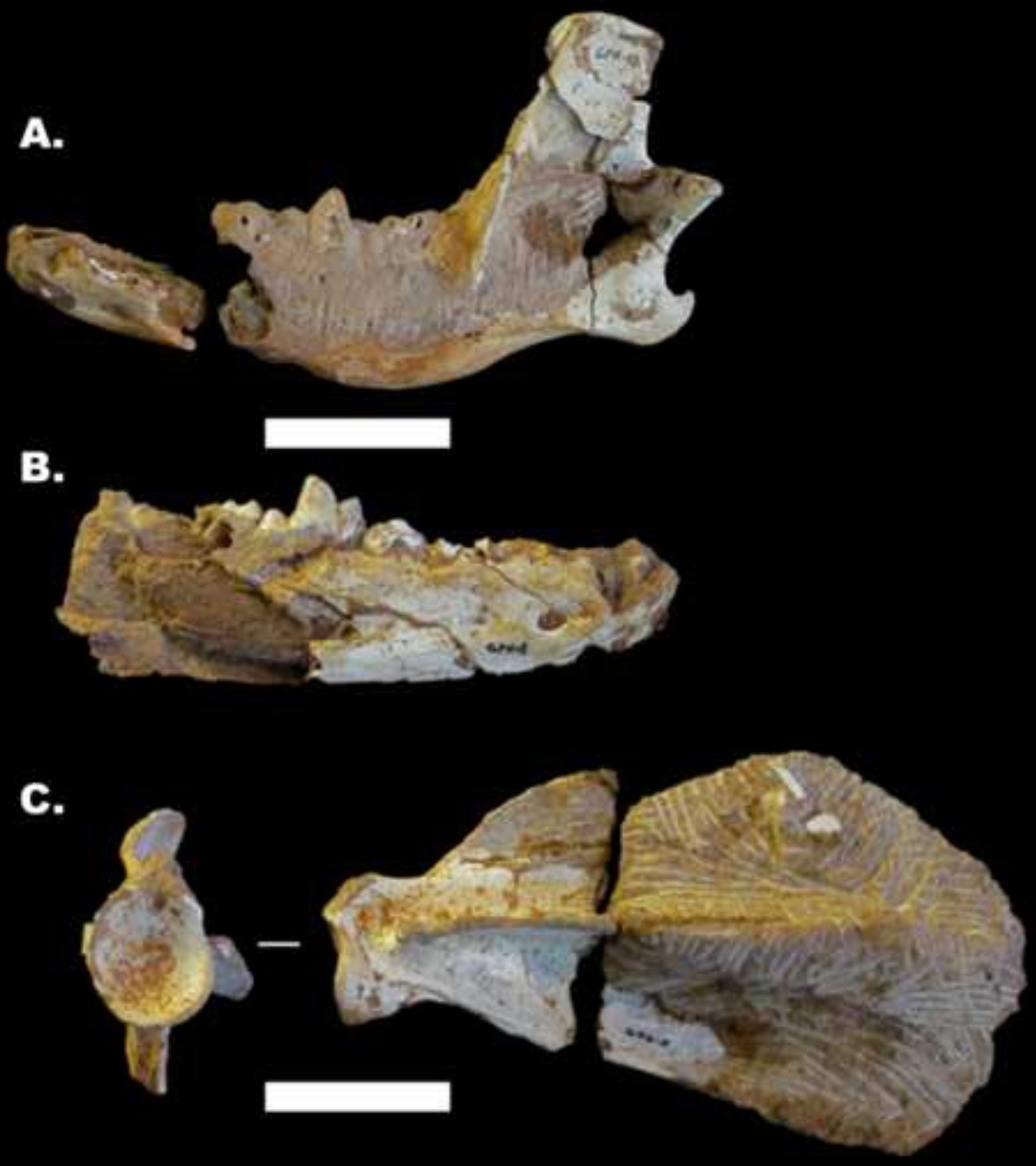

D.

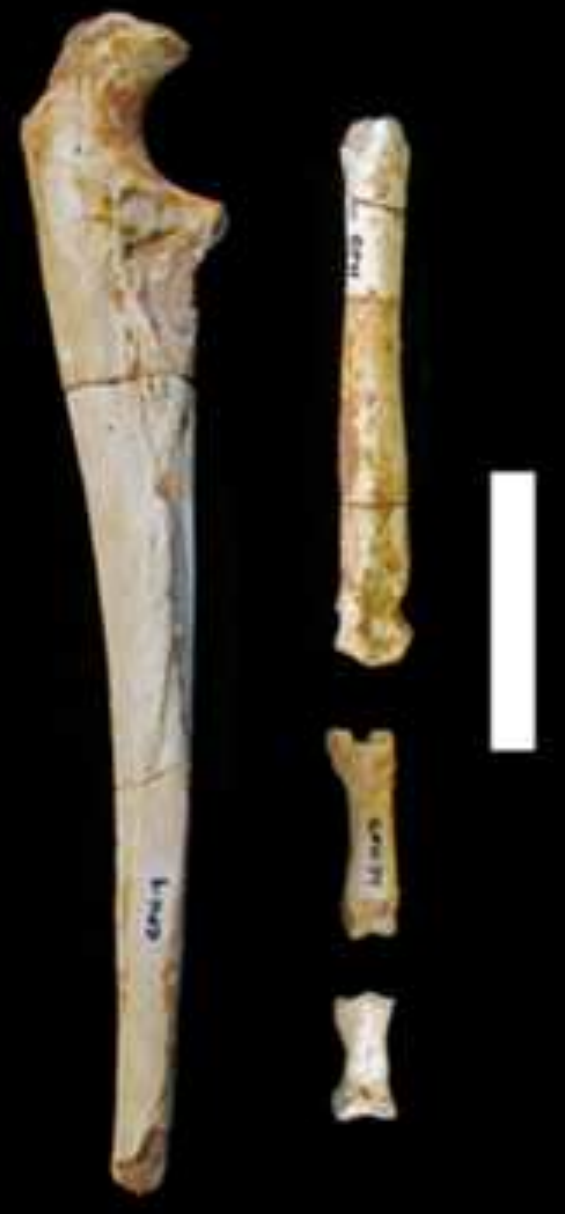



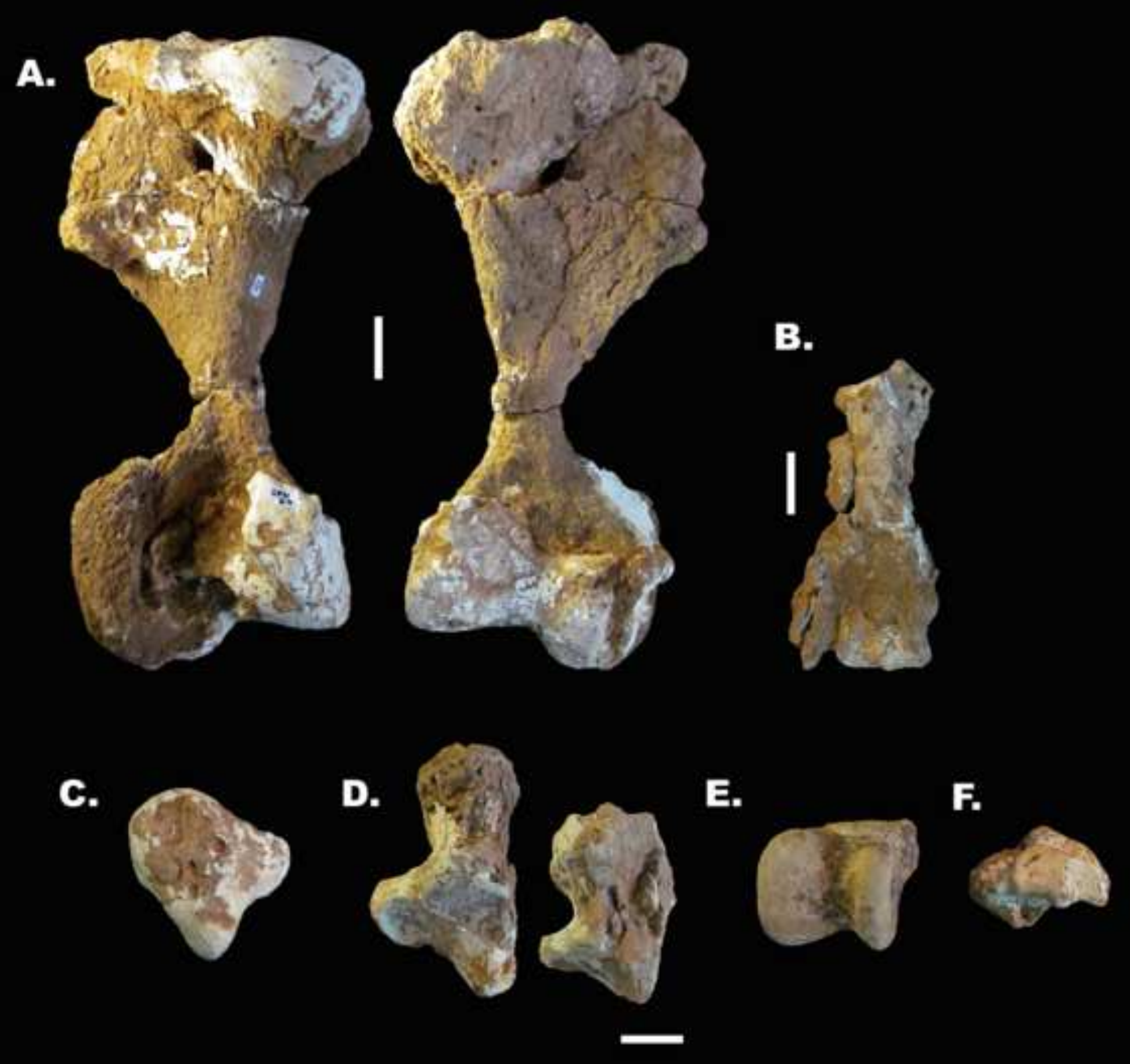

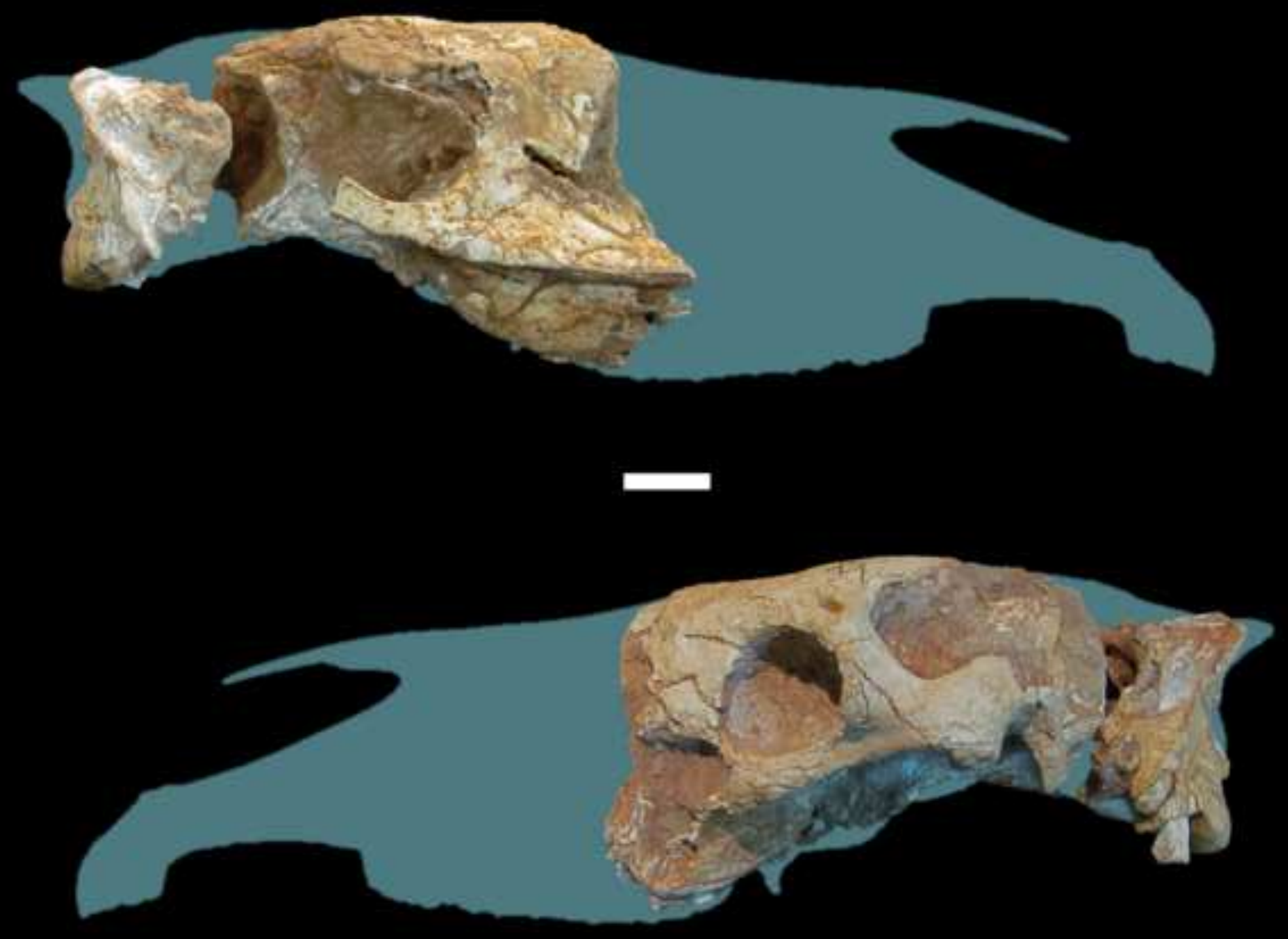

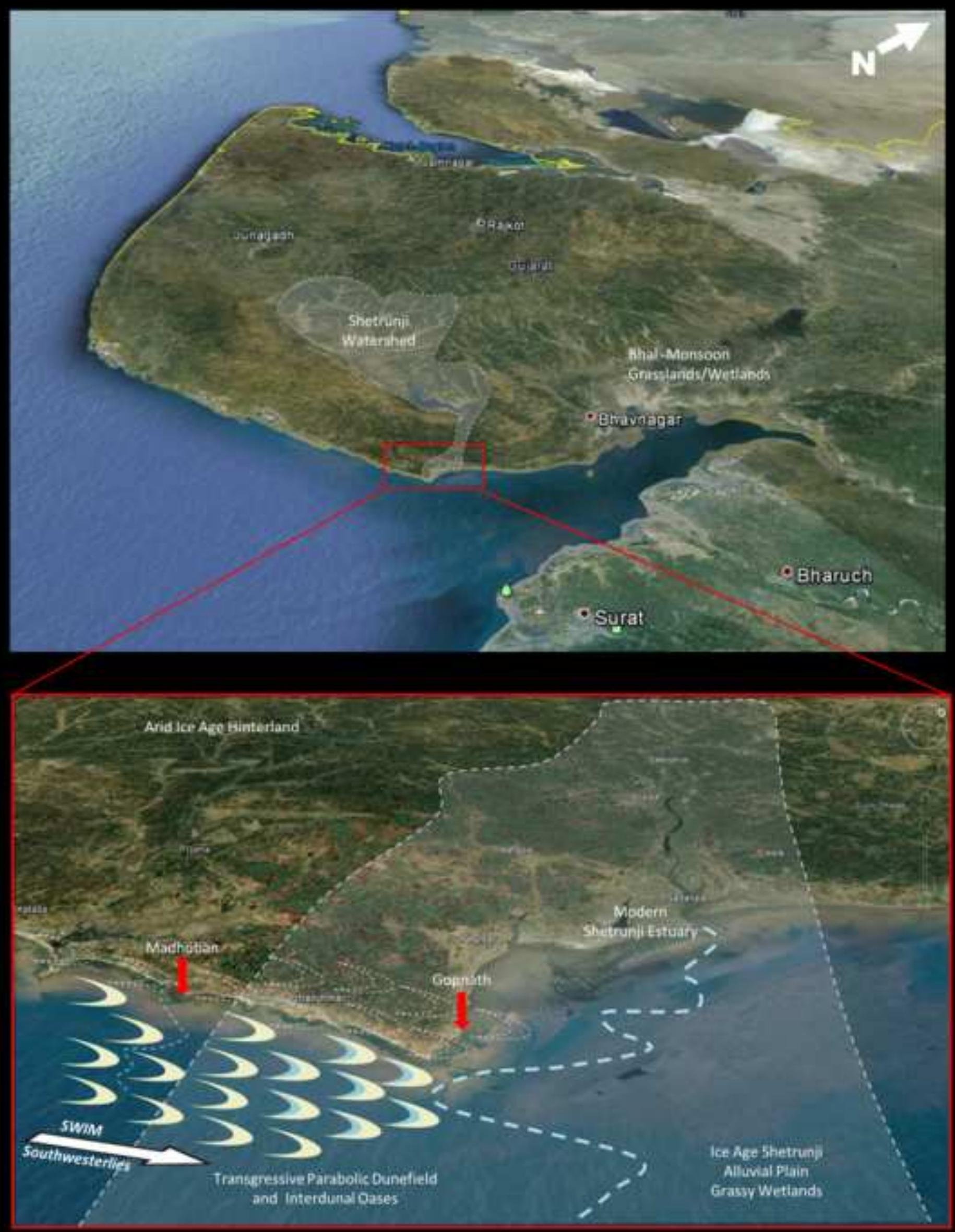


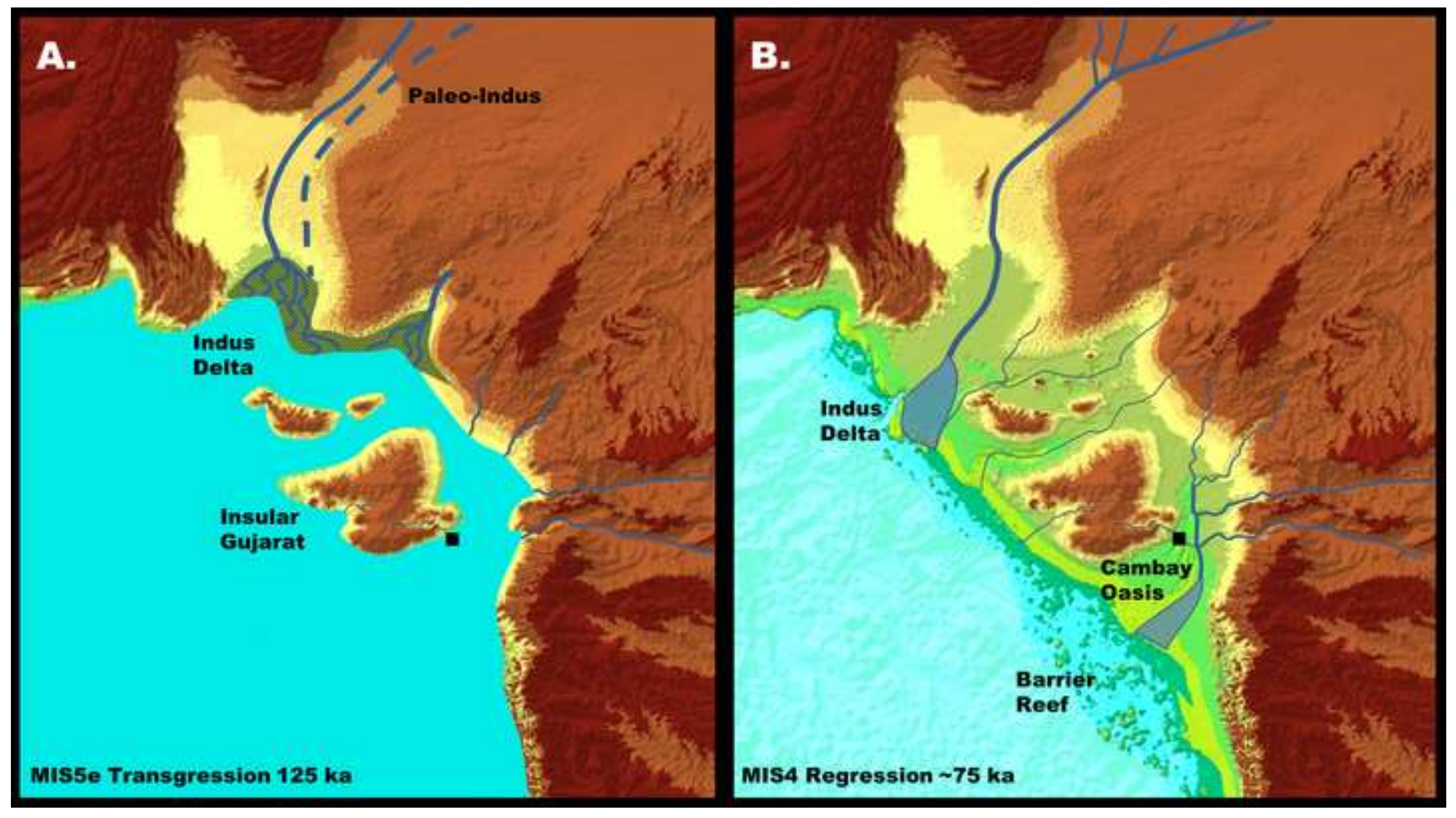


Taxa

Gastropoda

Subulinidae

Zootecus insularis

Reptilia

Testudinae

Geochelone sp.

Trionychidae

Nilssonia sp.

Mammalia

Canidae

Canis sp.

Equidae

Equus cf. E. sivalensis

Equus cf. E. hemionus

Rhinocerotidae

Rhinoceros cf. R. unicornis

Bovidae

Boselaphus sp.

Bubalus sp.

Bos sp.

Sivacobus sankaliai $\begin{array}{cc}\text { Modern } & \text { Modern } \\ \text { India } & \text { Gujarat }\end{array}$

$+\quad+$

$+\quad+\quad+$

$+\quad+\quad+$

$+\quad+\quad+$

$\begin{array}{lll}- & -\end{array}$

$\begin{array}{lll}- & +\end{array}$

$+\quad-\quad+$

$+\quad+\quad+$

$+\quad-^{*}+$

$-^{*} \quad-^{*}+$

$\begin{array}{lll}- & - & \end{array}$

* No extant wild aboriginal populations of Bos and Bubalus

Table 1. Fossil fauna from Gopnath. 


\begin{tabular}{|c|c|c|c|c|c|}
\hline & & \multicolumn{2}{|l|}{$\overline{P_{4}}$} & \multicolumn{2}{|c|}{$\overline{M_{1}}$} \\
\hline Specimen & & $\mathbf{L}$ & B & $\mathbf{L}$ & B \\
\hline Gopnath Canis sp. left mandible (GPN1) & & 17.7 & 7.2 & 27 & 11.4 \\
\hline Gopnath Canis sp. right mandible (GPN10) & - & - & & & 9.2 \\
\hline Canis cautleyi (Loc. 362. X124) & & 17.5 & 9 & 31.5 & 12.7 \\
\hline Canis cautleyi (BMNH_1) & - & - & & 27 & 10.7 \\
\hline Canis cautleyi (BMNH_2) & - & - & & 25.2 & 10 \\
\hline Langhnaj Canis Left Mandible & - & - & & 21.85 & 9.4 \\
\hline Langhnaj Canis Right Mandible & - & - & & 21.2 & 9.2 \\
\hline Canis lupus pallipes male mean & - & - & & 25.5 & 9.45 \\
\hline Canis lupus pallipes female mean & - & - & & 23.78 & 9.18 \\
\hline Canis lupus pallipes aggregate mean $(\mathrm{n}=16)$ & - & - & & 24.64 & 9.61 \\
\hline
\end{tabular}

